\title{
Bir Geçiş Ekonomisi Olarak Kırgızistan'da Doğrudan Yabancı Yatırımlar ve Orta Asya Ülkeleri İle Kiyaslanması*
}

\author{
Madina PASHALIEVA** Hamza KAHRIMAN ${ }^{* * *}$ \\ $\ddot{o} Z$
}

Sovyetler Birliği'nin dă̆ılmasıyla bağımsızlı̆̆ ilan eden ve piyasa ekonomisine geçmeye çalışan ülkelere geçiş ekonomileri denilmektedir. Bu ülkelerden birisi olan Kırgızistan, Orta Asya bölgesindeki stratejik konumu, liberal ekonomisi ve ılımlı yaklaşımı itibariyle gün geçtikçe daha fazla dikkatleri üzerine çekmektedir. Geçiş döneminin izlerini üzerinden atmaya çalışan ülke, yabancı yatırımları teşvik etmek üzere ciddi yasal ve yapısal düzenleme ve uygulamalara gitmiştir. Bu çalışmada, Kırgızistan Cumhuriyeti'nde sürdürülebilir büyüme ve refahın arttırllması amacıyla uygulamaya konulan politikalar sayesinde ülkenin yabancı yatırımları hangi düzeyde çekebildiği ve bölge ülkeleri ile klyaslandığında, durumunun ne olduğu ve sahip olduğu üstünlükler incelenmistir.

Anahtar Kelimeler: DYY, Kırgızistan, Orta Asya, Geçiş Ekonomileri

JEL Sinıflandirmasi: F21, F60, P33, O11

\section{Foreign Direct Investments in Kyrgyzstan as a Transition Economy and Its Comparison with Central Asian Countries}

\begin{abstract}
The countries which pronounced their independence after the dissolution of the Soviet Union and are endeavouring to shift to market economy are called transition economies. As one of these countries Kyrgyzstan is attracting more attention every other day due to its strategic position in Central Asia, its liberal economy and moderate approach. Trying to get rid of the traces of the transition period, this country has established serious legal and structural regulations and practices in order to promote foreign investments. This study deals with how much the Republic of Kyrgyzstan has managed to attract foreign investments thanks to the policies implemented for sustainable growth and improvement of welfare, and its status and superiorities when compared to other countries in the region.
\end{abstract}

Key Words: FDI, Kyrgyzstan, Central Asia, Transition economies

JEL Classification: F21, F60, P33, O11

\section{GİRIŞ}

Gelişmekte olan ülkelerin hedefledikleri kalkınma düzeyine ulaşma isteği, bu ülkeleri; sürdürülebilir bir ekonomik büyüme gerçekleştirilmeye, yatırım düzeyini yükseltmeye, uluslararası piyasalardaki rekabet gücünün artırmaya, daha fazla istihdam olanağı sağlanmaya ve teknolojik gelişmeyi sürekli hale

\footnotetext{
*Bu makale, Yrd. Doç. Dr. Hamza KAHRIMAN'ın danışmanlığında Madina PASHALIEVA tarafından 2015 yılında, Celal Bayar Üniversitesi Sosyal Bilimler Enstitüsü Maliye Anabilim Dalı Mali Hukuk Programı'nda yüksek lisans tezi olarak sunulup, kabul edilen "Kırgızistan'da Doğrudan Yabancı Yatırımlara Yönelik Teşvikler ve Orta Asya Ülkeleri İle Kıyaslanması” başlıklı çalışmadan yararlanılarak hazırlanmıștır.

** Mali Hukuk Bilim Uzmanı, madina.pashalieva@mail.ru

*** Yrd. Doç. Dr., ADÜ, Aydın İktisat Fakültesi Maliye Bölümü, hamza.kahriman @ adu.edu.tr 
getirilmeye zorlamaktadır. Gelişmekte olan ülkelerin genellikle yapısal darboğazları olan ve sermaye birikimi yetersizliği çeken ülkeler olduğu düşünüldüğünde, dünya genelindeki liberalleşme ve küreselleşme eğilimleri karşısında, gelişmekte olan ülkelerin mevcut potansiyellerini artırmaya çalışmaları kaçınılmaz hale gelmektedir. Durum böyle olunca, yatırım yapabilmek için gerekli tasarrufa sahip olmayan, diğer bir ifadeyle tasarruf açığ bulunan bu ülkelerin dış finansman kaynaklarından yararlanmak istemeleri zorunlu ve vazgeçilmez bir seçenek olarak ortaya çıkmaktadır (Bayraktar, 2003).

Sovyet Sisteminin dağılması ile beraber bağımsızlıklarını elde eden eski sosyalist ülkeler, piyasa ekonomisine geçiş sürecinde önemli ekonomik reform çabaları içerisine girmişlerdir. $\mathrm{Bu}$ ülke gruplarından birisi de Orta Asya ülkeleridir. Orta Asya ülkelerinde geçiş süreci her ülke için ekonomik, siyasal ve yapısal şartlar nezdinde izledikleri politikalar sonucunda farklı şekil almıştır. Geçiş ekonomisi ülkeleri için sermaye oluşumunun sağlanması açısından önemli olan özelleştirme sürecinin getirdiği doğrudan yabanc1 yatırımların ülke ekonomilerine sağladığı fayda ve etkileri hala hissedilmektedir. Bu ülkelerin çoğunun doğrudan yabanc1 yatırımlara bağımlılı̆̆ının olduğu ve refah seviyelerinin çok düşük olduğu bir gerçektir.

Kırgızistan'ın Orta Asya bölgesindeki stratejik konumu, liberal ekonomisi ve 1lımlı yaklaşımı itibariyle gün geçtikçe daha fazla dikkatleri üzerine çekmektedir. Geçiş döneminin izlerini üzerinden atmaya çalışan ülke, yabancı yatırımları teşvik etmek üzere ciddi yasal ve yapısal düzenleme ve uygulamalara gitmiştir. Orta Asya ülkelerinin çoğunda olduğu gibi Kırgızistan'da da en çok doğrudan yabancı yatırım çeken sektör madencilik ve maden arama faaliyetleridir. $\mathrm{Bu}$ çalışmada öncelikle doğrudan yabancı yatırımlar ile geçiş ekonomilerine ilişkin değerlendirmelere yer vereceğiz. Sonrasında ise bir geçiş ekonomisi olarak Kırgızistan Cumhuriyeti'nde sürdürülebilir büyüme ve refahın arttırılması amacıyla uygulamaya konulan politikalar sayesinde ülkenin yabancı yatırımları hangi düzeyde çekebildiği ve bölge ülkeleri ile kıyaslandığında, durumunun ne olduğu ve sahip olduğu üstünlükler ele alınacaktır.

\section{ACIKLAMALAR}

I. DOĞRUDAN YABANCI YATIRIMLARA İLIŞKINN GENEL

Yetersiz yatırım-kalkınamama sarmalı içerisinde kalan gelişmekte olan ülkelerin bu fasit daireden çıkabilmek için gerek duydukları sermaye birikimini yurt dışından sağlama çabaları karşımıza "yabancı yatırım" kavramını çıkarmaktadır (Gedikli, 2011). OECD (1996) ve IMF’e (1993) göre doğrudan yabancı yatırım, doğrudan yabancı yatırımcı tarafindan bir başka ülkede ya da ekonomide yerleşik olan teşebbüste kalıcı bir bağ (lasting interest) oluşturmak amacıyla yapılan bir uluslararası yatırım türüdür.

DPT (2000)'nin doğrudan yabancı yatırım tanımı ise, "Bir ülke borsasında işlem gören şirketlerin hisselerinin bir diğer ülke veya ülkelerin kuruluşları tarafindan satın alınmasinı ifade eden portföy yatırımları dişında kalan ve bir veya birden fazla uluslararası yatırımcinın tamamına sahip olarak 
veya yerli bir veya birkaç firma ile ortaklık halinde gerçekleştirdiği yatırımlar" şeklindedir.

Doğrudan yabancı yatırım (DYY) denildiğinde ilk akla gelen ve yaygınlaşmalarına temel etken olan faktörler küreselleşme ve çok uluslu şirketlerdir. II. Dünya Savaşı sonrasında ortaya çıkan yeni yatırım firsatları ve teknolojik gelişmeler, işletmelerin etkinliğine küresel bir boyut kazandırmıştır. Küreselleşme sürecinin hızlanmasına neden olan sebeplerin en başında hiç şüphesiz ki çok uluslu şirketler yer almaktadır. Çok uluslu şirketler bir zamanlar ulusal sınırlarla kısıtlı olan pazara bugün uluslararası boyutlar kazandırmışlardır (Aytemiz Seymen \& Çeken, 2004).

Çok Uluslu Şirketler (ÇUŞ) ve dolayısıyla doğrudan yabancı yatırımlarda I. Dünya Savaşı'ndan sonraki yıllarda dış ticareti dengeleyici politikaların kaldırılması sonucu artış meydana gelmiştir. Özellikle otomobil sanayinde dış ülkelere yapılan yatırımlar önem kazanmıştır. 1929 dönemindeki kriz sebebiyle şirketler stoklarını farklı pazarlarda eritmek zorunda kalmışlar, bu da uluslararası ticaretin artışına yol açmıştır. II. Dünya Savaşı'nın sona ermesi ile birlikte savaş döneminde atıl kalan uluslararası ticaret, Soğuk Savaş ile birlikte kutuplaşan dünyanın tercihlerine göre hareket etmeye başlamıştır. 1945- 1970 yılları arasında küresel bir genişleme dönemi olmuştur (Kaymakçı, 2013).

1970'lerde petrol krizinin çıkması ile doğrudan yabancı sermaye yatırımları artışında yavaşlama meydana gelmiştir. Bu yavaşlamanın yaşandığı dönemdeki, mevcut yabancı sermaye yatırımlarının büyük bölümü ise $\mathrm{ABD}$ kaynaklı olmuştur. 1980'li yıllarda sonra ise, özellikle Sovyet Birliği'nin yıkılmasından sonra, bu ülkeler ve Doğu Avrupa ülkelerinde yabancı sermaye yatırımlarında hem artış ve hem de çeşitlenme görülmüştür (Koçtürk \& Eker, 2012).

1995 y1lında GATT Uruguay Raundu alınan kararlar ile mal ve hizmet ticaretine ilişkin engellerin kaldırılması dünya ticaretin daha liberal bir hale getirmiştir. IMF ve Dünya Bankası gibi kurumların yapısal uyum programları ile gelişmekte olan ülkelerin izleyeceği liberalizasyon politikalarını desteklemesi ve doğrudan yabancı sermayenin gelmesini kolaylaştırıcı önlemlerin alınması şartının getirilmesi, gelişmekte olan ülkelerin dünya piyasaları ile bütünleşmesini hızlandırmıştır (Susam, 2008).

Herhangi bir ülkeye doğrudan yabancı yatırımların girişi söz konusu iken şirketler tarafından bir takım etken göz önünde bulundurulmaktadır. Doğrudan yabancı yatırımların temel belirleyicisi olan piyasanın büyüklüğünün ölçümünde nüfus ve milli gelirin büyüklüğü ele alınmaktadır. Piyasanın genişliği, ölçek ekonomilerinden kaynaklanan piyasada arz edilen malın maliyetini düşürmekte ve çıktı birim başına daha düşük maliyete sebep olmaktadır. Bundan dolayı pazarın olabildiğince geniş olması doğrudan yabancı yatırımını teşvik eden bir faktör olmaktadır (Kar \& Tatlısöz, 2008).

Doğrudan yabancı yatırımları teşvik eden diğer bir unsur da özendirici vergi ayrıcalıklarıdır. Doğrudan yabancı yatırımları özendirici vergi ayrıcalıkları, yatırımlardan elde edilen geliri daha düşük oranda vergilendiren, dolayısıyla 
vergiden sonraki getiri oranlarını yükselterek, yatırımların artırılmasını hedefleyen vergi araçları akla gelmektedir. Yalnız, doğrudan yabancı sermaye yatırımlarını özendirici vergi ayrıcalıklarının, yabancı yatırımcılara ülkenin yatırım iklimi konusunda bir nevi çağrı ve tanıtım yapmak amacıyla tanındığı düşüncesi de konunun bir başka yönünü oluşturmaktadır (Akkaya, 2003).

Doğrudan yabancı sermaye yatırımlarının yatırım kararında ana ülkedeki ekonomik ve siyasi faktörler de önemli bir şekilde etkili olmaktadır. Ekonomik etkenlerin dışında son zamanlarda doğrudan yabancı sermaye yatırımlarının ana ülkede siyasi istikrara daha fazla dikkat edilmesi ciddi bir gerçek haline gelmiştir. Ayrıca psikolojik ve ahlaki faktörler de yatırım kararlarında etkileyici diğer unsurlardir (Karaca, 2010).

Yatırımların gerçekleşmesinde yatırım yapılacak ülkenin sosyal ve ekonomik koşulları da diğer önemli bir konu olarak önem kazanmaktadır. Yabancı yatırımcı öncelikle sosyal ve kültürel açıdan kendi koşullarına benzer ülkeleri seçmektedir (Aydemir, Arslan, \& Uncu, 2012).

Yabancı yatırımcılar açısından dış ülkelerdeki yasalar kadar kendi ülkesindeki yasalar da önemlidir. Yatırımcının kendi ülkesindeki vergi düzenlemeleri ve anti tekelci politikalar yabancı ülkede yatırım yapma kararının alınmasında ciddi rol oynamaktadır. Yatırımcının ülkesindeki büyümeyi kısıtlayan mevzuat düzenlemeleri ve dezavantaj yaratan vergi kanunları yabancı ülkelerde yatırımları teşvik eder. Bunun yanında, yatırım yapılan ülkedeki düzenlemeler de yatırım kararı üzerinde önemli yere sahiptir. İzin verilen yabancı sermaye miktarı, vergileme ve kar aktarımı ile ilgili mevzuat yatırım kararını etkilemektedir (Sezgin, Y1ldz, \& Sezgin, 2011).

Doğrudan yabancı yatırımların günümüzdeki durumuna bakıldığında, başta Çin ve Hindistan olmak üzere, Uzakdoğu Asya ülkelerinin bu konuda öne çıktığını görmekteyiz. Çin ve Hindistan konvertibilite, yabancı sermaye teşvikleri, sermaye hareketleri kontrollerinin kaldırılması, devletin küçültülmesi, yazılım endüstrisi ve yüksek mühendislik gerektiren üretim dallarında belirgin ilerlemeler sayesinde geliştikleri bilinen bir gerçektir. Hindistan'da nüfusun okuma yazma oranının \%50 olmasına rağmen, ülkede dünyanın en gelişmiş roket ya da uyduların imalatı, uzay, atom ve silah teknolojisinde dünyanın liderleri arasında yer alması küreselleşmenin belirtileri olarak ifade edilebilir (Muter, Özdil, \& Yılmaz, 2002). Çin'de ise, bazı kısıtlamalar olmasına rağmen, dünyadaki yabancı sermaye yatırımlarının \%10'u gibi yoğun bir sermaye akışının sebebi, Çin'in yabancı sermayeye çok yönlü teşvikler sağlamasıdır. Çin' de büyük bir pazar ve işgücünün bulunması ve mal çıkışının kolay olması nedeniyle, birçok üründe günümüzde Çin damgasını görmek mümkündür (İnci \& Şahbazov, 2000). Çin’e giriş yapan yabancı doğrudan yatırımların sektörel dağılımına bakıldığında daha çok imalat sanayide yoğunlaştı̆̆ görülmektedir (İstanbul Ticaret Odası, 2007).

Birleşmiş Milletler tarafindan yapılan bir araştırmaya göre 90'lı yıllarda gelişmekte olan ülkelerde yatırım iklimiyle ilgili düzenlemelerin (toplam 750 adet) \%94,2'si doğrudan yabancı yatırımlara yönelik düzenlemeler olmuştur. 2001 yılında ise, 71 ülkenin doğrudan yabancı yatırım mevzuatında 208 değişiklik 
yapılmış ve bunların 194'ü doğrudan yabancı yatırımları özendirmek için yapılmıştır (Karagöz, 2007).

UNCTAD (2015) tarafindan yayımlanan 2015 Dünya Yatırım Raporu'na göre; Küresel DYY 2014 yılında, bir önceki yıla göre \%16 azalarak yaklaşık olarak 1,23 trilyon dolar seviyesinde gerçekleşmiştir. $\mathrm{Bu}$ düşüşün en önemli nedenlerini ise küresel ekonomideki kırılganlık, yatırımcılar açısından politik belirsizlik ve yüksek jeo-politik risklerdir. Yeni yatırımlar ise bazı büyük elden çıkarmalar ile dengelenmiştir. Gelişmekte olan ülkelere giren DYY miktarı bir önceki y1la göre \%2 artarak 681 milyar dolar seviyesi ile şu ana kadarki en yüksek düzeyine ulaşmıştır. Gelişmiş ülkeler için ise durum hiç de iç açıcı değildir. Gelişmiş ülkelere yönelik DYY girişi, 2013 yılına kıyasla \%28 oranında düşerek, 499 milyar dolar seviyesine gerilemiştir. Bölgesel bazda bakıldığında, gelişmekte olan ülkelere yönelik en çok DYY girişi Asya bölgesindeki, özellikle de Doğu ve Güneydoğu Asya ülkelerine doğru olmuştur. Doğu ve Güneydoğu Asya ülkelerine giren DYY miktarı, aynı zamanda bölgesel bazda tüm dünyadaki en yüksek DYY giriş miktarını ifade etmektedir. Bir önceki y1l 348 milyar dolar olan Doğu ve Güneydoğu Asya ülkelerine yönelik DYY girişi, \%10 artarak 381 milyar dolar seviyesine yükselmiştir. 2014 yılında DYY girişi en dramatik biçimde düşen bölgelerden birisi ise Geçiş Ekonomileri olmuştur. 2013 yılında 100 milyar dolar olan DYY girişi \%52 düşerek, 48 milyar dolar seviyesine gerilemiştir. Ülke bazında bakıldığında ise 129 milyar dolar DYY girişi ile Çin, 2014 yılında en çok DYY çeken ülke olmuştur. Çin'e giren DYY miktarı bir önceki y1l 124 milyar dolardı. Çin'i sırasıyla 103 milyar dolar ile Hong-Kong, 92 milyar dolar ile ABD, 72 milyar dolar ile Birleşik Krallık, 68 milyar dolar ile Singapur takip etmektedir.

Tablo 1. Bölgeler İtibariyle Doğrudan Yabancı Yatırım Akışları, 2012-2014 Yılları İtibariyle (Milyar Dolar)

\begin{tabular}{lcccccc} 
& \multicolumn{3}{c}{ DYY Girişi } & \multicolumn{3}{c}{ DYY Çıkışı } \\
\hline BÖLGELER & 2012 & 2013 & 2014 & 2012 & 2013 & 2014 \\
\hline Dünya Geneli & $\mathbf{1 . 4 0 3}$ & $\mathbf{1 . 4 6 7}$ & $\mathbf{1 . 2 2 8}$ & $\mathbf{1 . 2 8 4}$ & $\mathbf{1 . 3 0 6}$ & $\mathbf{1 . 3 5 4}$ \\
Gelişmiş Ekonomiler & 679 & 697 & 499 & 873 & 834 & 823 \\
Avrupa & 401 & 326 & 289 & 376 & 317 & 316 \\
Kuzey Amerika & 209 & 301 & 146 & 365 & 379 & 390 \\
Gelişmekte Olan Ekonomiler & 639 & 671 & 681 & 357 & 381 & 468 \\
Afrika & 56 & 54 & 54 & 12 & 16 & 13 \\
Asya & 401 & 428 & 465 & 299 & 335 & 432 \\
$\quad$ Doğu ve Güneydoğu Asya & 321 & 348 & 381 & 266 & 292 & 383 \\
Güney Asya & 32 & 36 & 41 & 10 & 2 & 11 \\
Batı Asya & 48 & 45 & 43 & 23 & 41 & 38 \\
Latin Amerika ve Karayipler & 178 & 186 & 159 & 44 & 28 & 23 \\
Okyanusya & 4 & 3 & 3 & 2 & 1 & 0 \\
Geçiş Ekonomileri & 85 & 100 & 48 & 54 & 91 & 63 \\
\hline
\end{tabular}

Kaynak: (UNCTAD, 2015). 


\section{GEÇİŞ EKONOMILERİ VE GENEL REFORM SÜRECİ}

1989 yılında Berlin Duvarının yıkılmasıyla birlikte üç komünist ülke; Çek Cumhuriyeti, Yugoslavya ve Sovyetler Birliği 22 farklı ülkeye ayrılmıştır. Yeni bağımsızlık sürecinde olan bu ülkelere "geçiş ekonomileri" adı verilmiştir. IMF tarafindan yapılan tasnife göre, Merkezi ve Doğu Avrupa (MDA), Baltık Devletleri ve günümüzdeki Bağımsız Devletler Topluluğu (BDT) bunların yanı sıra aynı süreçten geçen Asya ülkeleri geçiş ekonomileri adı altında yer almaktadır $^{1} .2002$ yılında ise, geçiş ülkeleri içerisine Bosna Hersek, Sırbistan ve Karadağ da eklenmiştir. 2009 yllında da bu gruba en son dâhil edilen ülke ise, Kosova Cumhuriyetidir.

EBRD'in tanımlamasıyla geçiş, belirgin bir şekilde daha yönelimli ekonomi tesis etmeye yönelik süreçtir; ekonomik yapıda değişimi ve yeni kurumlar oluşturmayı içerir. Kumanda ekonomilerindeki temel sorunlar, fonksiyonel sisteminin olmayışı ve fiyat sistemini desteklemede ve mülkiyet haklarını korumada yasal ve finansal kurumların bulunmamasıdır (Değer \& Emsen, 2005). EBRD'nin geliştirmiş olduğu yıllık geçiş göstergeleri raporları, geçiş ülkelerinde yapısal reform surecinin bütünüyle tamamlanmamış olduğunu göstermektedir (Gökbunar v.d., 2016).

Merkezi planlama sistemine dayalı bir ekonomik ve siyasi yapıdan piyasa ekonomisine geçişi ve daha sonrasında dönüşümü sağlamak oldukça karmaşık ve zaman alan bir süreçtir. Bu kavramlar kültürel, ekonomik ve politik yönler açısından farklı anlam taşımaktadırlar. Buradaki "geçiş" kavramı belirli bir başlangıç noktasından bilinen bir son noktaya doğru eylemli bir süreci ifade etmektedir. Dönüşüm ise, uzun dönemli olarak politik sistemler arasındaki yakınlaşmanın ve teknolojik değişimin bir sonucu olarak, ekonomik ve politik bakımlardan sistematik ve sürekli bir değişimi ifade etmektedir (Sakınç, 2005).

Geçiş ekonomilerinin temel özellikleri Havrylyshyn ve Wolf (1999) tarafindan aşağıdaki gibi özetlenmiştir:

- Ekonomik faaliyetlerin, fiyat ve piyasa işlemlerinin serbestleşmesi (liberalleşmesi) ve akabinde daha etkin kullanımın sağlanması için kaynakların yeniden tahsisi;

- Makroekonomik istikrar ve dengenin sağlanması için dolaylı ve piyasa odaklı enstrümanların geliştirilmesi;

- Özelleştirme yoluyla etkin işletme yönetimi ve ekonomik etkinliğin elde edilmesi;

- Ekonomik etkinliği geliştiren teşvikleri sağlayan sıkı bütçe politikalarının uygulanması ve

\footnotetext{
${ }^{1}$ Orta ve Doğu Avrupa Ülkeleri (ODA): Arnavutluk, Bulgaristan, Hırvatistan, Çek Cumhuriyeti, Macaristan, Makedonya, Polonya, Romanya, Slovak Cumhuriyeti ve Slovenya; Baltık Devletleri: Estonya, Letonya, Litvanya.;BDT Ülkeleri: Azerbaycan, Ermenistan, Beyaz Rusya, Gürcistan, Kazakistan, Kırgızistan, Moldova, Rusya Federasyonu, Özbekistan, Tacikistan, Türkmenistan ve Ukrayna; Asya'daki Geçiş Ekonomileri: Çin, Kamboçya, Laos ve Vietnam.
} 
- Mülkiyet haklarının, kanun hükümlerinin ve pazara giriş düzenlemelerinin şeffaf olduğu bir kurumsal ve yasal çerçeve oluşturulmasıdır.

Geçiş ekonomileri birbirlerine benzeyen özellikleri nedeniyle diğer ülkelerden ayrışmaktadır. Kişi başına düşen milli gelirde, sanayide istihdam edilen işgücü oranındaki benzerlikler, kullanılan enerji miktarı, yaygın bir altyapının varlığı dönüşüm sürecindeki ülkelerin temel özelliklerindendir. Ancak piyasa ekonomisine geçiş açısından bir değerlendirme yapıldığında ise, farklı ülke grupları ortaya çıkmaktadır (Egeli \& Emsen, 2002).

Geçiş ekonomilerinde, sosyalist sistemden serbest piyasa ekonomisine geçiş sürecini yaşayan ülkeler makro ekonomik istikrarı sağlamak ve ayrıca yeniden yapılandırılma gereği olan ekonomik, mali ve sosyal reformlar da yürütmeye başlamıştır. Bu reformlar uluslararası finans kurumlarının denetiminde devam etmiş, ne yazık ki bu reformların uygulamaya kondukları ülkede bu deneyimlerin sonucunda elde edilen başarılar farklı boyutlar kazanmıştır. Reform paketlerinden farklı başarı elde edilmesi, uygulayan ülkelerin yapısal koşullarına ve uygulama etkinliklerine bağlı olarak farklılık göstermiştir (Arıkan, 2002).

Eski Sovyetler Birliği ve ODA ülkeleri arasındaki geçiş döneminin başlangıcındaki çok ileri düzeydeki kurumsal, jeopolitik ve kültürel benzerliklere rağmen, geçişin başlamasından bu yana çok farklı yönlerde ilerlemiş oldukları açık olarak görülmektedir. $\mathrm{Bu}$ farklılıklar, her şeyden önce uygulanan politikaların bir sonucu olmuştur. Geçiş aşamasının başlamasından itibaren bu ülkelerin karşılaştığı zorlukların benzer olmasına rağmen, göstermiş oldukları büyüme performanslarını belirleyen kurumsallaşma göstergeleri ve ülke ekonomilerinin potansiyelleri arasındaki farkl11ıklar önemli etken olmuştur. Ayrıca, ilk başta benzer kurumsal düzenlemelere sahip olan ülkeler farklı politikalar uygulayabilir ve bu politikalar sonucunda aynı kurumsal çerçeve içinde faklı sonuçlar elde edilebilir. Belirli ülkedeki problemlere uygun görülen politikalar, diğer ülkelerde uygulandığ 1 takdirde ayn1 olumlu sonucu yaratmayabilir (Balcılar, 2002).

Dünya Bankası 2002 y1lında Doğu Avrupa ve Eski SSCB ülkelerinin 1991 yılından 10 yıllık bir geçiş sürecini incelemeye almıştır. Bu araştırma sonucunda ele edilen veriler geçiş süreci esnasında ülkelerin büyüme ve performansları arasındaki farklılıklar giderek yoğunlaşmıştır. Çıkan sonuçların çok keskin olarak ülkelerin geçiş sürecinde başlangıç koşullarının büyük rol oynadığı ve ancak daha ciddi etkenin ülkeler tarafından tesis edilen reform politikaları olduğu tespit edilmiştir. Ayrıca bu çalışma yeni firmaların piyasaya girişi ve büyümesi, özellikle küçük ve orta ölçekli olanların, istihdam yaratma ve ekonomik büyümeyi sağlama konusunda büyük rol oynadığ 1 belirlenmiştir. Buna ilaveten, politika yapıcıların, ekonominin yeni sektörlerine yeni firmaların girişini teşvik edecek stratejilere yönelmeleri gerekliliğine dikkat çekmiştir (KoyameMarsh, 2011).

Geçiş sürecindeki reformların yapılmasına ilişkin iki yöntem önerilmektedir. Yöntemlerden birincisi, "şok terapi" ya da "büyük patlama” diye 
adlandırılan ve radikal bir biçimde kurumsal sistemin değişimini gerçekleştiren yöntemdir. İkincisi ise kademeli bir biçimde reform yapılmasını öneren yöntemdir.

Washington Mutabakatı 1şığında oluşturulan "şok terapi" ya da "büyük patlama" diye adlandırılan yöntem, eş anlı radikal olarak kurumların sisteminin değişimini kasteden alternatif bir yöntemdir. Genellikle bu yöntem diğer daha gelişmiş kurum sistemlerinin deneyimlerinden esinlenerek ilgili kanunların uygulama bulması ile bağdaşır. Bu yöntemle ilgili yapılan eleştiriler hızlı ve ani kararların alınması ve uygulanması, olası zararların önüne geçilmesi açısından son derece güç bir durum olmasıdır (Polterovich, 2006).

Reformun aşamalı yapılması gerektiğine inanan görüş (Gradualizm) ise, zamanlamaya önemli ölçüde vurgu yapmakta ve reformların sırasıyla ve yavaş yavaş uygulanması gerekliliğini savunmaktadır. Böylece yeni reformların birbirlerinin sonuçlarını etkisiz hale getirmeyecek şekilde bir sonraki aşamaya geçilebilmesini ancak olumlu şartların varlığı veya uygun olduğu takdirde mümkün olduğunu ileri sürmektedir. (Staehr, 2003).

Geçiş ülkeleri, 1990 yılından itibaren bir yandan sıkı maliye ve para politikaları uyguladıkları gibi bir yandan da dış ticaretin liberalleștirilmesi, özelleştirme ve yabancı sermayenin teşviki gibi unsurları hızlı ekonomik gelişme ve kalkınmanın sağlanması için geniş kapsamlı bir şekilde uygulamaya koymuşlardır. Uygulanan ekonomik politikalar, yabancı sermayeli firmaları özellikle özelleştirilen devlet firmalarına yatırım yapmaya yönlendirilmeyi amaçlamaktadır. Özelleştirme yoluyla yabancı sermayenin ülkeye çekilmesinde çoğunlukla devlet mülkiyetinde olan özelleştirilen firmanın hisse senetlerinin yabancı firmalarca satın alınmasına izin verilmesi yöntemi uygulanmaktadır. 1994 yılından itibaren özelleştirme ve yabancı sermaye yatırımları arasındaki ilişki belirgin olarak Polonya, Macaristan, Çek ve Slovak Cumhuriyetleri'nde görülmüş ve giderek hız kazanmıştır (Dural, 2007).

Geçiş aşamasında yeni bir vergi sisteminin ve yapısının oluşturulması bu sürecin en karmaşık kısımlarından biridir. Sovyetler Birliği döneminde yürürlükte olan vergi sistemi ciro ve devlet teşebbüslerinin karları üzerinden alınan vergilere dayanıyordu. Vergi yönetimi etkin ve gelişmiş olmaktan çok uzaktı. Maliye teşkilatının etkinliği zayıftı ve bütçe tahsisleri önceden tespit edilmiş bazı orantı ve kriterlere göre yapılmaktaydı. Serbest piyasa ekonomisine geçişle ve fiyatların serbestleşmesi ile geleneksel vergi yapısının değişmesi ve piyasa şartlarına uygun hale gelecek kadar geliştirilmesi gerekmekteydi. Devlet teşebbüslerinin özelleştirme yoluyla küçük ve orta ölçekli işletmelere dönüşmesinden dolayı şirketlere yönelik yeni vergi düzenlemeleri gerekmiştir (Ağcakaya, 2009). Fiyat liberalizasyonu, tekelci yapının tasfiyesi özelleştirme yanında bir ilk olarak Kurumlar Vergisinin uygulamaya konması büyük ilgi çeken hususlar olmuştur (Altay, 2001).

29 geçiş ülkesinin panel veri analizine dayanarak yapılan çalışmada, ülkelerin bütçe dengelerindeki bozulmaların özelleştirmeden kaynaklandığ 1 , özellikle de özelleştirme ve vergi gelirleri arasında ters bir ilişkinin olduğu 
saptanmıştır. Zamanında gerçekleştirilmeyen vergi reformlarının ve oturtulmayan vergi idaresinin piyasa odaklı bir ekonomide bütçe sürecinin ve özelleștirmenin etkinliği açısından negatif sonuçlara neden olabileceğini göstermiştir. Özelleştirme esnasında ve sonrasında geçiş ekonomilerinin yatırım çekebilmeleri için maliye politikasının araçları olarak vergi muafiyetleri ve tercihli vergi rejimleri gibi uygulamaların yaygınlığı vergi matrahındaki eksilmelere neden olmuştur. Bu gelir kaybı gibi olumsuzlukların giderilmesi için Doğu Avrupa ülkelerinin Katma Değer Vergisi gibi yeni tedbirlerin kullanılması örnek olarak gösterilebilir. Bunlara bir diğer örnek de, reformların benimsenmesi açısından kolaylık sunan vergi teşviklerinin imtiyazlı olarak sağlanmasıdır (Crivelli, 2013).

\section{KIRGIZISTAN'DA DOĞRUDAN YABANCI YATIRIMLAR}

1991 yılında bağımsızlı̆̆ını elde ettiğinden itibaren, Kırgızistan Cumhuriyeti hem siyasi hem de ekonomik açıdan ciddi sorunlarla karşılaşmıştır. Yüksek rakamlara ulaşan dış borç, istikrarsılılılar ve siyasal iktidar tarafından görev suiistimali 2005 ve 2010 yıllarında olmak üzere halkın desteği ile darbelerle ülkeyi karşılaştırmıştır. 2010 yılında yaşanan olayların ardından Orta Asya'da parlamenter sisteme geçen ilk ülke Kırgızistan olmuştur (UNDP, 2015).

Birçok BDT ülkelerinin aksine, Kırgızistan'ın sahip olduğu doğal kaynakları açısından zengin olmadığından dolayı yolsuzluk konusu değerlendirildiğinde pay alınacak bir pastanın olmadığına işaret etmektedir. Ayrıca, Kırgizistan'ın diğer Orta Asya ülkelerine kıyasla daha hızlı reformcu olduğu söylenebilir. Reform sürecinin devletin ekonomiye müdahalesin azaltılmasına yönelik politikaları içermesi ise yolsuzluk açısından önemli avantaj olarak görülmektedir. Bağımsızlığını elde ettiğinden itibaren ülkede fiyat liberalizasiyonu, ticari ve tarım mevzuatındaki reformlar, özellikle küçük ve orta ölçekli işletmelerin özelleştirilmesi ve serbest ticari rejime tabi tutulması olarak sıralanabilir (Çokgezen, 2004).

\section{A. Kırgızistan'da Doğrudan Yabancı Yatırımlara Yönelik Mevzuat}

Bağımsızlığın ilk günlerinden itibaren ülkedeki ilgili mevzuatın gelişimi 1991 yılında Kabul edilen "Kırgızistan Cumhuriyeti'nde Yabancı Yatırımlar Hakkında" Kanun ile başlamıştır. Ardından Kırgızistan Cumhuriyeti'nde Yabancı Yatırım faaliyetleri ile ilişkili konuları düzenlemek ve hukuki temel teşkil etmek üzere 24 Eylül 1997 yılında "Kırgızistan Cumhuriyeti'nde Yabancı Yatırımlar Hakkında" Kanun yürürlüğe konmuştur.

1998 yılında BDT ülkeleri arasında Kırgızistan ilk olarak Dünya Ticaret Örgütüne (DTÖ) üye olmuştur. Gelişmekte olan ülke statüsünde üyeliğe kabul edilen ülke çoğu koşullara cevap vermemekteydi. Bu rağmen devlet tarafından yabancı yatırımcılar için ülke piyasasındaki her sektöre giriş serbestliği sunulmuştur. Ayrıca aynı yıl içinde referandum sonucunda yabancı yatırımcılar için de toprak sahipliği imkânı tanınmıştır (Abdurazakov, 2008). Kırgızistan'ın yabancı yatırımlara açıklık derecesi yüksek olduğu halde Dünya Ticaret Örgütü üyeliği yatırım faaliyetlerinde aşırı dalgalanma yaratmamıştır. Buna engel olan başlıca faktörlerden bazıları doğal kaynaklar, rekabetçi sanayi eksikliği ve iç pazarın düşük kapasitesi olmuştur. Halen ekonominin cazip sektörü olarak 
hidroelektrik enerji üretimi görülmektedir. Ancak bu sektörün geliştirilmesi için Orta Asya bölgesinde bu alandaki işbirliği eksikliğinin aşılması gerekliliği ön plana çıkmaktadır (Anisimov, 2011). Kırgızistan'ın 252 orta ve büyük nehrin toplam enerji kapasitesi 160 milyar kwt elektrik enerjisi teknik kapasitesi 100 milyar kwt'dır. Kazakistan, Özbekistan, Tacikistan ve Çin'e yapılan enerji ihracatı toplam teknik kapasitesinin onda bir kısmı kullanilarak gerçekleştirilmektedir (Sayrakunova, 2010). Su gücünün yanında 2 milyar ton kömür rezervi, 89 milyon ton petrol rezervi, 65 milyon ton demir rezervi, 255 milyon ton alüminyum rezervi, 5 milyar ton gaz rezervi ve 900 ton civarında altın yatakları tespit edilmiştir (Ünver, 2012).

27 Mart 2003 tarihli "Kırgızistan Cumhuriyeti'nde Yatırımlar Hakkında" Kanunun en son hali yabanc1 yatırımc1 ile yerli yatırımcı arasındaki farkı tamamen kaldırarak devlet imtiyazlarının belirli bölgelerde ve öncelikli sektörlerde sağlanacağı garantisini sunmaktadır (Supataeva, 2011). Bu kanun kapsamında vergi mevzuatı dışındaki yatırımlarla ilişkili mevzuatta yapılan değişikliler neticesinde yatırımcı getirilen değişiklik tarihinden itibaren on yıl için kendisi için en uygun koşulları seçmekte özgür bırakılmıştır.

Orta Asya ülkeleri içinde bir ilk olan, 25 Mayıs 2007 tarihli Kırgızistan Cumhuriyeti "Girişimciliğin Devlet Desteği Hakkında" Kanun girişimci ve küçük işletmelerin faaliyetlerinin desteğini ve gelişimini sağlayan devlet teşviklerinin yöntem ve şekillerinin düzenlenmesini yerine getirmektedir. Bu kanun sayesinde devlet ve girişimciler arasında verimli bir işbirliği ve güvenilir bir yatırım ortamına erişim sağlanmaya çalışılmıştır.

25 Mayıs 2007 yılın ayında kabul edilen "İşletme Denetim Prosedürlerinin Usulüne İlişkin" Kanunu usulsüz denetimlerin sayısı ve zamanın azaltılması ve kanuni olmasına şartlar altında yapılmasına vurgu yapmıştır.

Bundan ayrı 20 Şubat 2009 yılında kabul edilen "Tüzel Kişilerin ve Şubelerinin Devlet Tescili Hakkında ${ }^{\mathrm{x}}$ kanun kapsamında "tek pencere" uygulaması ile yatırımcılara gerekli evrak, prosedür ve süre açısından kolaylıklar sunulması ile beraber tek kurum aracılığ ile işlemlerinin tamamlaması mümkün hale gelmiştir (World Bank Group, 2010). Buna destek olarak, 28 Ocak 2011 tarihli "Tüzel Kişilik ve Şube Tescili Hususları Hakkında" 31 Nolu Kırgızistan Cumhuriyeti Hükümeti Kararnamesi devlet tescilinin tek mercii tarafından yapılmas1 ve ilgili işlemlerin düzenlenmesi ve kolaylaştırılması yönünde gerekli önlemlerin alınmasında ilk adım olmuştur (KCMMO, 2011).

Hükümet Basın Bürosunun verdiği bilgiye göre 27 Mart 2013 tarihinde Ekonomi Bakanlığı tarafindan Yatırım Promosyon Ajansı resmen kurulmuştur. Proje 2013-2017 Ulusal Sürdürülebilir Kalkınma Stratejisinin öngördüğ̈̈ doğrudan yabancı yatırımları teşvik etmek ve ilgili görevleri yerine getirmek üzere Kırgızistan Cumhuriyeti Ekonomi Bakanlığı tarafından geliştirilmiş̧ir. Yeni ajans ülkenin yatırım cazibesini arttırmak için yatırım faaliyetlerini teşvik etmek için gerekli önlemlerin uygulanmasını gerçekleştirecektir. Devlet organları, yerel yönetimler, iş dünyası ve özel sektörün yatırım projelerinin ve programlarının uygulanmasında kamu-özel sektör etkileşimini sağlayacaktır. Ayrıca ulusal 
altyapı projeleri ve yatırım programlarının gerçekleştirilmesine katılacak ve ekonominin öncelikli sektörlerine yatırımları çekmek için elverişli koşulların yaratılması yoluyla ekonomideki sektörlerin çeşitlendirilmesini teşvik edecektir. Yatırım çekmek adına uluslararası ve bölgesel dış ekonomik ilişkilerin geliştirilmesi de ajansın önceliklerinden olacaktır (Levina, 2014).

\section{B. Kırgızistan'da Doğrudan Yabancı Yatırımların Güncel Durumu}

Kırgızistan ekonomisi en az rekabetçi ve uluslararası kabul görmüş yönetim göstergelerine göre dünyanın en yüksek yolsuzluk oranına sahip olan ülkeleri arasında yer almasına rağmen bu bağlamda son zamanlarda yayınlanan orta vadeli 2013-2017 Ulusal Sürdürülebilir Kalkınma Stratejisi yönetişimin geliştirilmesi ve hesap verilebilirlik açısından güven vericidir. Buna ilave olarak, 2011 yılın Mart ayında Maden Sanayi Şeffaflık Girişimi (Extractive Industries Transparency Initiative/ EITI) petrol, doğal gaz ve madencilik açısından gelişmiş olan 11 ülke arasında bu statüye tam uyumlu olduğu ilan edilmiştir (World Bank, 2013a). 2011 yılında ülkedeki altın madenciliği sektöründeki en büyük yabancı yatırımcı şirket Kumtor tek başına ülkenin GSYİH' sının \% 11,7 oranını ulaşmıştır, bu da toplam ülke ihracatın \% 51,1'lik payını oluşturmaktadır (Musaev, 2013). 2012 EITI Raporuna göre Kirgizistan Cumhuriyeti madencilik faaliyeti gelirleri; bütçe gelirlerinin yaklaşık \%11'ini, GSYİH'nın \%7'si ve toplam ihracatın \%44'nü oluşturmaktadır. Altyapı ve yatırım eksikliği, ciddi kapasiteye sahip olan kömür, kalay ve tungsten rezervlerinin gelişimini engellenmektedir (Extractive Industries Transparency Initiative (EITI), 2011).

Centerra Gold şirketinin dünya çapında en büyük sekizinci altın madeni olan Kumtor payı üzerinde hükümetle devam eden anlaşmazlık ülke görünümünde riskin oluşmasına neden olabilir. 2013 yılının Eylül ayında Centerra Gold hisselerinin \%33'nün Kumtor altın madeni hissesinin \%50'ye değişmeyi öngören mutabakatını imzalamıştır. İlk başlarda parlamentonun karşı çıktığı anlaşma 2014 yılında detaylı olarak koşullarının inceleneceği ve müzakere edileceği üzerine onay almıştır (Asian Development Bank, 2014). Tüm tartışmalar 2009 y1lında imzalanan ve ülke ekonomisinin toplam katma değerinin \%10'ni üreten Kumtor şirketini vergi rejimindeki değişikliklere karşı koruyan yatırım anlaşması üzerinde yoğunlaşmıştır. Devlet komisyonu daha yüksek yaklaşık 315 milyon \$ (ülke GSYİH'nın \%5'i ) miktarında çevre vergisi getirmeyi tavsiye etmiştir. 2013 yılının ikinci yarısından itibaren hükümetin talimatı ile 2009 Yatırım Anlaşması tek taraflı fes edilmişs sayılmaktadır (EBRD, 2014).

Ülkenin en büyük ortakları \% 59 oranı ile Bağımsız Devletler Topluluğu dışındaki ülkelerdir (1623 şirket), diğger kısmı ise (1144 şirket) Bağımsız Devletler topluluğu ülkeleridir. 2013 yılında işletmelerin ağırlıklı payı Rusya(\%21), Kazakistan (yaklaşık \%16), Çin $(\% 14,2)$ ve Türkiye $(13,3)$ olmak üzere ayrılmıştır. Yabancı sermayeli şirketlerin en fazla yoğunlaştı̆̆ araç, ev aletleri ve kişisel eşyaların tamiri ve ticareti(\% 32,6), gayrimenkul işlemleri, kiralama(20,2), ve ayrıca imalat sanayi(17,7). Yabancı sermayeli şirketlerin yaklaşık \%84'lük kısmı Bişkek şehrinde faaliyet göstermektedir 
(Национальный статистический комитет Кыргызской Республики (K1rgizistan Cumhuriyeti Milli İstatistik Komitesi), 2014).

Tablo 2. Kırgızistan'da Faaliyette Bulunan Başlıca Ülkeler ve Şirket Sayısı (2012-2013)

\begin{tabular}{lcccc}
\hline \multirow{2}{*}{ Ülkeler } & \multicolumn{2}{c}{ Toplam Şirket Sayıs } & \multicolumn{2}{c}{ Tamamen Yabancı Sermayeli } \\
\cline { 2 - 5 } & $\mathbf{2 0 1 2}$ & $\mathbf{2 0 1 3}$ & $\mathbf{2 0 1 2}$ & $\mathbf{2 0 1 3}$ \\
\hline ABD & 72 & 73 & 31 & 30 \\
Almanya & 69 & 68 & 22 & 24 \\
Birleşik Krallık & 37 & 40 & 17 & 20 \\
Çin & 370 & 395 & 239 & 250 \\
İran & 81 & 77 & 60 & 58 \\
İsviçre & 20 & 23 & 7 & 11 \\
Kanada & 18 & 25 & 10 & 15 \\
Kazakistan & 401 & 438 & 164 & 187 \\
Kore & 112 & 125 & 70 & 84 \\
Kuzey Kıbrıs & 24 & 30 & 10 & 18 \\
Özbekistan & 43 & 45 & 21 & 23 \\
Rusya & 561 & 581 & 181 & 187 \\
Tacikistan & 12 & 11 & 6 & 7 \\
Türkiye & 341 & 368 & 242 & 268 \\
\hline Toplam & 20601 & 2767 & 1319 & 1448 \\
\hline
\end{tabular}

Kaynak: (Национальный статистический комитет Кыргызской Республики (Kırgızistan Cumhuriyeti Milli İstatistik Komitesi), 2014).

Kırgızistan'daki toplam yatırım girişi düzensiz eğilim sergilemektedir. 2006-2012 yılları arasında doğrudan yabancı yatırımların toplam içindeki payı $\% 13,4$ ile \%1,7 oranında artış göstermiştir. Doğrudan yabancı yatırımların girişi de ayrıca dalgalı bir seyir ile GSYİH’ in \%9-\%17 oranları arasında değişmiştir. $\mathrm{Bu}$ endeksin değeri uluslararası uygulamalara göre GSYIH' in \%25 oranının yeterlilik göstergesi eşik değerinin altındadır. Son yıllarda yabancı yatırım girişleri Kanada ve Çin'den sağlanmaktadır. Kanadalı yatırımlar madencilik sektörüne katkıda bulunurken, Çin tarafından gerçekleştirilen yatırımlar küçük ve orta ölçekli yatırımların yanı sıra büyük ölçekli yatırım projelerinde de boy göstermektedir. 2010 yılına kadar Bağımsız Devletler Topluluğu ülkelerinden gelen yatırımların en büyük kaynağı Kazakistan olmuştur. Doğrudan yabanc1 yatırımlar için cazibe yaratmaya devam eden büyük çoğunlukla imalat sanayi sektörü iken, hizmetler sektöründe ticaret, gayrimenkul işlemleri, kira ve müşteri hizmetlerinde de bir artı̧̧ meydana gelmiştir (WTO, 2013).

2010 yılında Kambar-Ata HES-2 devreye girmesi ile elektrik kayıplarında \%32 oranında bir düşme meydana gelmiştir. Yeni ve mevcut hidroelektrik santrallerin yeniden inşası ile üretken kapasitelerinin genişletilmesi, iletim hatlarının geliştirilmesi sayesinde ilk öncelikle yerli tüketiciler için güvenilir bir güç kaynağı ve ihracat amaçlı özel yatırımların teşviki için enerji sektöründe ciddi önlemler alınmaya devam etmektedir (WTO, 2013).

Kırgızistan yetkilileri turizm sektörünü teşvik edilmesi gereken en önemli sektör olarak belirlemişleridir. Büyük ölçüde gelişmemiş olsa da, sektörün 
ülkedeki son yıllardaki büyüme oranı \% 40 üzerine çıkmıştır. 2011 y1lında 640 milyon \$'lık gelir getiren sektör GSYİH' nın \%11. 2' lik payını oluşturmuştur. Turizmin diğer sektörlerle olan bağlılığı da söz konusudur. Ülkedeki uluslar arası turizmin canlanması ile tarım, imalat (el sanatları ve hazır giyim dahil), ticaret, finans, sağllk ve dinlence ve diğer ilgili sektörlerin gelişimine de destek sağlayacağı beklenmektedir (UNCTAD, 2013). Ülke doğas1, temiz havası ve suyu ile yazın Issık-Göl kumsalı, kışın da çeşitli kayak sporları ile bölgedeki ülkelerden gelen turistlerin ilgisini çektiği kadar gerekli altyapı ve tesislerin kurulması ile tanıtımının dünya çapında daha geniş olarak yapıldığı takdirde eşi bulunmayan bir turistik merkez olabilir (UNCTAD, 2013).

Çin, Kazakistan ve Rusya gibi hızla gelişmekte olan ülkeler ile coğrafi yakınlığı sayesinde Kırgızistan ciddi olarak ihracatını genişletebilme potansiyeline sahiptir. Ancak bu avantajlara rağmen halen ülke tarım (pamuk, tütün, deri işleme), hizmet, madencilik(büyük ölçüde altın), inşaat malzemeleri ve hafif sanayi üretimi üzerinde yoğunlaşmıştır (UN, 2010).

Turizm sektörü ülke milli gelirinin \%10 oluşturmaktadır. Enerji üretimi ülkedeki GSMH' nın \%2'lik kısmına tekabül etmektedir. Ülkedeki hidro-elektirik potansiyelinin sadece \%8-9,5'lik payı kullanım görmektedir. Patente tabi basitleştirilmiş vergilendirme sistemi sayesinde ivme kazanan ve bölgedeki tekstil tedarikini sağlayan ve ülke ihracatında altından sonra ikinci yere sahip olan tekstil sektörü ülke ekonomisinin "lokomotifi" olarak görülmektedir (Investment Promotion Agency, 2015). "Legprom" ve "Soyuztekstil" tekstilci dernekleri tarafindan sunulan rakamlara göre, 2012 y1lında Kazakistan ve Rusya Federasyonuna ihracat yapan 3000 küçük ve orta büyüklükteki işletme ile, giyim sanayi tüm hafif sanayinin \%80' den fazlasını oluşturmuştur (Jenish, 2014).

Tarım Kırgızistan' da her ne kadar organize edilmemiş olsa da tarım en büyük ekonomik sektördür (Yereli, Yıldız, \& Ayyıldız, 2007). Geleneksel tekniklerle yapılsa da 19994.9 kilometrelik ülke alanının 10591.3 kilometre tarıma elverişli alanı mevcuttur (FAO, 2015). Buğday, arpa, mısır(tahil ve silaj), patates, kavun, karpuz, kuzey bölgede (Talas) baklagiller(fasulye), güneyde ise, pamuk ve tütün yetiştirilmektedir (Fitzherbert, 2006).

Mikro finans kuruluşları her ne kadar giderek önemli rol oynasa da Kırgız finans sistemi küçük ve daha çok banka egemen bir yapıdadır. Kırgız finans piyasasında 24 tane ticari banka, 16 tane sigorta şirketi, iki emeklilik fonu ve döviz bürosu, mikro finans kurumları gibi çok sayıda banka dışı kuruluşlar mevcut. Yabancı bankalar (ağırlıklı olarak Kazak ve Rus) bankacılık sisteminin \%48'ni oluşturmaktadır. Mali aracılık kuruluşları düşük kredi ve mevduat girişi ile bölgedeki en düşük oranda gözlemlenmektedir. Avrupa ve Orta Asya bölgesinde kredi göstergeleri açısından 2014 yılı sıralamasında on üçüncü sırada yerini almıştır (World Bank Group, 2015). 


\section{DOĞRUDAN YABANCI YATIRIMLAR BAKIMINDAN KIRGIZISTAN'IN DIIĞER ORTA ASYA ÜLKELERININ KIYASLANMASI}

Orta Asya petrol doğal gaz, kömür ve metal cevherlerini içeren zengin doğal kaynaklara sahiptir. Bu kaynaklar bölgedeki ülkeler arasında eşitsiz olarak dağılmıştır. Kazakistan petrol ve doğal gaz rezervleri açısından zengin iken ülkede aynı zamanda kömür, demir, krom, altın ve diğer metal cevherleri mevcuttur. Özbekistan'ın doğal gaz ve bir miktar petrol rezervleri vardır. Kırgizistan altın ve hidroelektrik enerjisine sahipken, Tacikistan da hidroelektrik enerjisinin yanı sıra bazı uranyum ve petrol rezervleri mevcuttur (Penev, 2007). Orta Asya ülkeleri eski Sovyet ülkeleri olarak değerlendirildiklerinde, bir taraftan uzun süreli ortak tarihsel ve ekonomik geçmiş ve sıkı karşılıklı ilişkilere sahipler. Orta Asya ülkeleri arasında devletlerarası işbirliğinin istenilen seviyede olmamasına rağmen, bölgede "aşağıdan yukarıya doğru" entegrasyon izlenmektedir. Yatırımların yoğunlaştığı sektörler metalürji ve telekomünikasyon iken, son zamanlarda sermaye yatırımların çeşitlendirilmesi yanı sıra ortak girişim ve sıfırdan yatırım türlerinde artışlar gözlemlenmektedir. Bu ülkeler arasında altyapı(demir yolu ve elektrik enerjisi) açısından bağlantılı birilik mevcut. Ayrıca, bölgede büyük ölçekli iş gücü akışının yanında sosyal bütünleşme açısından Rusçanın ortak dil olarak ciddi unsur teşkil etmesi bir diğer önemli noktadır (Libman, 2009).

İmalat sanayi yapısı ve imalat ihracatının yapısı ülkeden ülkeye önemli ölçüde farklılık göstermektedir. Bazı ülkeler basit emek yoğun sektör odaklı ihracat yapısına yönelirken, diğerleri daha karmaşık sermaye ve teknoloji yoğun sektörlere hâkim olmaktadır. Ülke düzeyindeki ihracat modelleri karşılaştırmalı avantajları, teşvik politikaları ve yurtdışı pazarları ile tarihsel bağlantı durumunu yansıtmaktadır. Tekstil ve konfeksiyon imalatının ihracatı (Türkiye ve Kore'li yatırımcılar kısmen) Tacikistan'da \%80'lere ulaşırken Kırgızistan' da bu oran $\% 37$ seviyelerindedir. Bu arada Kazakistan'ın imalat ihracatı demir çelik ve bazı kimyasal ve plastik üretimi yanı sıra makine ve nakliye ekipmanlarından oluşmaktadır (Dowling \& Wignaraja, 2006).

Tablo 3. Orta Asya Ülkelerinde Temel Göstergeler

\begin{tabular}{lcccc}
\hline Ülkeler & Kazakistan & Özbekistan & Tacikistan & Kırgızistan \\
\hline GSYH (milyar \$) & 224.4 & 56.80 & 8.508 & 7.226 \\
Alan km ${ }^{2}$ & 2.724 .9 & 447,400 & 143,100 & 199,951 \\
Nüfus milyon & 17.04 & 30.24 & 8.208 & 5.720 \\
İSKD* (milyon \$) & $10,021.6$ & $1,512.8$ & 544.7 & 374.6 \\
İSKD'nin GSYİH pay1 & $\% 11$ & $\% 6$ & $\% 14$ & $\% 11$ \\
REP (136) & 69 & - & 121 & 118 \\
Büyüme Oranı (2013) & $\% 6.0$ & $\% 8.2$ & $\% 7,4$ & $\% 10.5$ \\
Enflasyon & $\% 5.8$ & $\% 7.0$ & $\% 5.0$ & $\% 6.6$ \\
\hline
\end{tabular}

* İSKD: İmalat Sanayi Katma Değeri, REP: Rekabetçi Endüstriyel Performans.

Kaynak: ( World Bank, 2014; Trading Economics, 2014).

Azam (2010) tarafindan 1991 ve 2009 yılları arasında Ermenistan ve Orta Asya Ülkeleri Türkmenistan, Kırgızistan Cumhuriyeti gibi ülkelerde, doğrudan yabancı yatırımların ekonomik belirleyicilerinin etkileri üzerine araştırma 
yapılmıştır. Söz konusu araştırma sonuçları, yapılan çalışma süresince pazar payının ve resmi kalkınma desteğinin doğrudan yabancı yatırımlar üzerinde olumlu ve enflasyonun olumsuz etki yarattığını göstermiştir. Ancak Kırgızistan durumunda ise, enflasyonun doğrudan yabancı yatırımlar üzerinde önemsiz ancak negatif işaretli etkiye sahip olduğu saptanmıştır. Ancak bu doğrudan yabancı yatırımlar üzerinde önemsiz göstergelerin etkisi olmadığı anlamına gelmez, bunun faydalanılan mevcut verilerin eksik olması durumu ile ilgili bir sorun da olabilir. $\mathrm{Bu}$ araştırma neticesinde elde edilen sonuçlar, piyasa payının güçlendirilmesi, enflasyonla mücadele edilmesi ve resmi kalkınma desteklerinin sağlanması ile doğrudan yabancı yatırımları daha ileri düzeye teşvik edebildiği ve hususunu önermektedir.

Aralarında Orta Asya Ülkelerinin de yer aldığı, yüksek ve düşük performansla ilişkili önemli faktörlerin incelemesine yönelik olan Endüstriyel Rekabet Performans siralamasinda, dört faktör endüstriyel rekabet performans üzerinde önemli etkiye sahiptir. Bunlar; ekonomik teşvik rejiminin reformu, endüstriyel teknoloji geliştirme becerilerinin kazanılması ve altyapı inşaatı. Bu faktörler ekonomik teşvik rejiminin ve ekonominin önemli arz yönlü açıların ve bunların endüstriyel rekabet etkileşimini temsil etmektedir. Piyasa dostu ekonomik teşvik rejimi makroekonomik istikrar, düşük ithalat koruma seviyesi ve akıcı bürokratik işlem hızı rekabetçi üretim faaliyeti için esastır. Böyle bir rejim endüstriyel işletmelerin rekabet, yatırım için öngörülebilir bir ortam, üretimde ölçek ekonomileri ve düşük işlem maliyetlerinin faydalarını görmelerini sağlamaktadır (Dowling \& Wignaraja, 2006).

Tablo 4. Ülkelerin Rekabet Edilebilirlik Derecelerine Ait Bazı Göstergeler (144 ülke)

\begin{tabular}{|c|c|c|c|c|c|c|}
\hline & \multicolumn{2}{|c|}{$\begin{array}{l}\text { Kurgızistan } \\
\text { Cumhuriyeti }\end{array}$} & \multicolumn{2}{|c|}{$\begin{array}{l}\text { Kazakistan } \\
\text { Cumhuriyeti }\end{array}$} & \multicolumn{2}{|c|}{$\begin{array}{l}\text { Tacikistan } \\
\text { Cumhuriyeti }\end{array}$} \\
\hline & Sira & Değer & Sira & Değer & Sira & Değer \\
\hline $\begin{array}{l}\text { Küresel Rekabet Edilebilirlik Endeksi Genel } \\
\text { Siralaması (144ülke) }\end{array}$ & 108 & 3.73 & 50 & 4.42 & 91 & 3.93 \\
\hline $\begin{array}{l}\text { İş Mevzuatının DYY' a Etkisi } \\
\text { (1-caydırıcı,7-teşvik edici) }\end{array}$ & 107 & 3.9 & 78 & 4.4 & 121 & 3.6 \\
\hline $\begin{array}{l}\text { İş Başlatmak İçin Gerekli } \\
\text { Prosedür Sayısı }\end{array}$ & 3 & 2 & 57 & 6 & 32 & 5 \\
\hline İş Başlatmak İçin Gerekli Gün Sayısı & 39 & 8.0 & 62 & 12.0 & 116 & 33.0 \\
\hline $\begin{array}{l}\text { Yatırımcıların Korunması } \\
\text { (10 en iyi) }\end{array}$ & 22 & 6.7 & 22 & 6.7 & 22 & 6.7 \\
\hline $\begin{array}{l}\text { Ticari Engellerin Yaygınlığ1 } \\
\text { (1-yüksek engel,7-engel yok) }\end{array}$ & 37 & 4.6 & 63 & 4.4 & 133 & 3.7 \\
\hline Ticari Tarifeler $(\%)$ & 109 & 10.7 & 101 & 9.4 & 73 & 5.7 \\
\hline $\begin{array}{l}\text { Toplam Vergi Oranı (Kurumlar Vergisi, İşgücü } \\
\text { Vergisi ve Katk1 ve Diğer Vergilerin \%) }\end{array}$ & 51 & 33.4 & 33 & 28.6 & 141 & 86.0 \\
\hline
\end{tabular}




\begin{tabular}{|c|c|c|c|c|c|c|}
\hline $\begin{array}{l}\text { Vergilendirmenin Yatırım } \\
\text { Teşvikine Etkisi } \\
\text { (1-düşürüyor, 7-düşürmüyor) }\end{array}$ & 99 & 3.4 & 37 & 4.0 & 123 & 3.1 \\
\hline $\begin{array}{l}\text { Ülke Kredi Derecelendirmesi } \\
\text { (0-100en düşük borç temerrüt olasılığ })\end{array}$ & 96 & 33.6 & 48 & 60.4 & 129 & 19.9 \\
\hline $\begin{array}{l}\text { Altyapı Kalitesi } \\
\text { ( } 7 \text { Dünya Çapında En Gelişmiş) }\end{array}$ & 96 & 3.6 & 62 & 4.4 & 107 & 3.4 \\
\hline $\begin{array}{l}\text { Düzensiz Ödemeler ve Rüşvet } \\
\text { (1-yaygın, 7-hiç yok) }\end{array}$ & 132 & 2.6 & 80 & 3.8 & 87 & 3.6 \\
\hline
\end{tabular}

Not: Özbekistan hakkında yeterli kaynaklara ulaşılamadığından dolayı rapor kapsamında yer almamaktadır.

Kaynak: (World Economic Forum, 2015).

Dikkat çeken nokta, değerlendirmede adı geçen ülkelerin hepsinin yatırımcıların korunması açısından aynı göstergelere sahip olduklarıdır. Kazakistan genel itibariyle diğer iki ülke ile kıyaslandığında tüm göstergeler açısından daha avantajlı konumda yer almaktadır. Tacikistan ise, tam tersine daha düşük değerlerle dünya standartlarının çok altında bir seyir göstermektedir. Kırgızistan Tacikistan'a kıyasla bu ölçütler itibari ile çok ilerlemiş olmasa da iş başlatmak için gerekli prosedür sayısının 2 olması koşulu ile dünya sıralamasında üçüncüdür.

Kırgız Cumhuriyeti yatırım iklimini ve rekabet edebilirliğini geliştirmek ve elverişli iş ortamı yaratmak için bir dizi önlem almıştır. Bunlar; yatırım ve diğer iş faaliyetlerinde idari engellerin ve kısıtlamaların ve devlet organları tarafından gereksiz müdahalelerin ortadan kaldırılması, piyasa ilişkilerinin düzenlenmesinde yeni yaklaşımların tanıtılması, iş adamları ve yatırımcılar için güvenilirliğini ve kredibilitesini arttırmak için sırasıyla ülkenin bankacılık sistemini iyileştirilmek için önlemlerin alındığını sıralamak mümkün. Bundan ayrı, düzenleyici şartlara uyum maliyetlerinin azaltılması öngören yeni mevzuatın tanıtılması ile çeşitli zorunlulukların ortadan kaldırılmasını sağlanmıştır. Kurucuların noter tasdikli imza zorunluluğu, finans şirketi olmayan şirketlere minimum stok sermaye şartı, çeşitli kayıt sonrası ücretler, şirket tescili için gerekli olan banka hesabı açma şartı geçerliliğini kaybetmiş olan zorunluluklardır (WTO, 2013).

Bölgedeki yatırımları korumak ve teşvik etmek amacıyla, Kazakistan, 43; Kırgızistan, 27; Tacikistan, 32; Özbekistan, 50 ülke ile kaşıklıklı anlaşma imzalamıştır. $\mathrm{Bu}$ anlaşmalar muafiyetler ve aynı zamanda herhangi bir ülkede ödenen vergiler için krediler sağlayarak elde edilen gelir için çifte vergilendirme konusunda rahatlık sunmaktadır. Bazı çifte vergilendirmeyi önleme anlaşmaları, teknik hizmetler için faiz, royalty veya ücreti net bazda tahsil edilmek üzere tasalanmıştır (Paswan, 2013).

Kırgızistan Hükümeti son dönemlerde yatırım ortamının iyileştirilmesi ve ülkede ciddi seviyede görülen yolsuzluğun azaltılması konusuna vurgu yapmaktadır. Ülke, ilk başta yatırımcıların korunması (22.sıra); firmaların krediye erişimini kolaylaştırmak için kredi bürolarının açılması (13. sıra); ve daha kolay bir şekilde bir iş başlatmak (12.sıra) ve tescil işlemlerini 
hızlandırmak(9.sıra) için çeşitli düzenleyici yasalar ve yönetmelikler çıkartarak dünya sıralamasında yükselerek önemli yol kat etmiştir.

Tablo 5. Bazı Orta Asya Ülkelerinde İş Yapma Kolaylığı Açısından Sıralaması (2014)

\begin{tabular}{lcccccccc}
\hline & \multicolumn{2}{c}{ Kazakistan } & \multicolumn{2}{c}{ Kurgızistan } & \multicolumn{2}{c}{ Özbekistan } & \multicolumn{2}{c}{ Tacikistan } \\
\cline { 2 - 9 } & $\mathbf{2 0 1 4}$ & 2013 & $\mathbf{2 0 1 4}$ & 2013 & $\mathbf{2 0 1 4}$ & 2013 & $\mathbf{2 0 1 4}$ & 2013 \\
\hline İș Yapma Kolaylığı & $\mathbf{5 0}$ & 53 & $\mathbf{6 8}$ & 70 & $\mathbf{1 4 6}$ & 156 & $\mathbf{1 4 3}$ & 141 \\
İş Kurma & $\mathbf{3 0}$ & 27 & $\mathbf{1 2}$ & 14 & $\mathbf{2 1}$ & 87 & $\mathbf{8 7}$ & 77 \\
İnşaat Ruhsatı İşlemleri & $\mathbf{1 4 5}$ & 149 & $\mathbf{6 6}$ & 62 & $\mathbf{1 5 9}$ & 160 & $\mathbf{1 8 4}$ & 184 \\
Elektrik Temini & $\mathbf{8 7}$ & 85 & $\mathbf{1 8 0}$ & 179 & $\mathbf{1 7 3}$ & 169 & $\mathbf{1 8 6}$ & 186 \\
Gayrimenkul Tescili & $\mathbf{1 8}$ & 27 & $\mathbf{9}$ & 6 & $\mathbf{1 3 6}$ & 142 & $\mathbf{7 8}$ & 78 \\
Kredi Temini & $\mathbf{8 6}$ & 82 & $\mathbf{1 3}$ & 11 & $\mathbf{1 3 0}$ & 154 & $\mathbf{1 5 9}$ & 182 \\
Yatırımcıların Korunması & $\mathbf{2 2}$ & 21 & $\mathbf{2 2}$ & 21 & $\mathbf{1 3 8}$ & 137 & $\mathbf{2 2}$ & 21 \\
Vergi Ödeme & $\mathbf{1 8}$ & 18 & $\mathbf{1 2 7}$ & 123 & $\mathbf{1 6 8}$ & 165 & $\mathbf{1 7 8}$ & 179 \\
Sınır Ötesi Tícaret & $\mathbf{1 8 6}$ & 186 & $\mathbf{1 8 2}$ & 184 & $\mathbf{1 8 9}$ & 189 & $\mathbf{1 8 8}$ & 188 \\
Sözleşmelerin & $\mathbf{2 7}$ & 26 & $\mathbf{7 0}$ & 69 & $\mathbf{4 0}$ & 42 & $\mathbf{3 9}$ & 39 \\
Uygulanması & $\mathbf{5 4}$ & 55 & $\mathbf{1 3 2}$ & 155 & $\mathbf{6 3}$ & 71 & $\mathbf{8 1}$ & 78 \\
İflasın Çözümü (Tasfiye) & $\mathbf{5 4}$ & & & & & & &
\end{tabular}

Diğer Orta Asya ülkelerinden olduğu gibi, Kırgızistan'da da altyap1 yetersiziliği, yatırım yapma yolunda kilit nokta ve önemli bir engeldir. Zayıf olan elektrik arzı, enerji kayıplarının önüne geçilmesi ve tüketim verimliliğinin arttırılması gereken temel bir sorun olarak görülmektedir. Bunun yanı sıra yetersiz olan ulaşım altyapısı da özel sektörün gelişimini baltalayan önemli bir unsurdur.

Kırgızistan Cumhuriyeti özel sektörü belirgin büyüme potansiyeline sahiptir. Ülkede özel sektörün GSYİH payı \% 75'tir. Bu oran, Kazakistan'da $\% 65$, Tacikistan'da \%55, Özbekistan'da \%45'tir. Tekstil ve giyim sektörü gibi belirli sektörlerde yoğunlaşma olmasına rağmen, Kırgızistan özel sektörün üretken kapasitesini genişletmek ve istihdam sağlamak yolunda sınırlı da olsa ilerleme kaydetmiştir. İmalat, turizm, telekomünikasyon ve ulaşım oldukça hızlı büyüyen ve buna bağlı olarak da birçok sektörü genişletme potansiyeline sahip olan sektörlerdir. Kırgızistan Cumhuriyeti iç piyasasında adil rekabeti sağlamak ve özel sektör gelişimini etkinleştirmek mecburiyetindedir (Houérou, 2012)

Tablo 6. Son Yıllarda Orta Asya Ülkelerine Yönelik Doğrudan Yabancı Yatırım Girişi (Milyon Dolar)

\begin{tabular}{lrrrrrr}
\hline & $\mathbf{2 0 0 9}$ & $\mathbf{2 0 1 0}$ & $\mathbf{2 0 1 1}$ & $\mathbf{2 0 1 2}$ & $\mathbf{2 0 1 3}$ & $\mathbf{2 0 1 4}$ \\
\hline Kazakistan & 13.243 & 11.551 & 13.973 & 13.337 & 10.221 & 9.562 \\
Özbekistan & 842 & 1.636 & 1.635 & 563 & 686 & 751 \\
Kirgizistan & 189 & 438 & 694 & 293 & 626 & 211 \\
Tacikistan & 97 & 74 & 160 & 232 & 105 & 261 \\
\hline
\end{tabular}

Kaynak: (UNCTAD, 2016).

Bölge ülkelerindeki yabancı yatırım akışları önemli ölçüde değişim göstermektedir. Bölge ülkeleri içinde en yüksek DYY çeken ülke Kazakistan'dır. Kazakistan'1 sırasıyla Özbekistan ve Kırgızistan izlemektedir. Bölgenin en az DYY çeken ülkesi ise Tacikistan'dır.

Kazakistan'ın 2003 yılında 17 milyar 587 milyon dolar DYY giriş stoku 2014 yılında 129 milyar 244 milyon dolara; Özbekistan'ın 2003 yılında 929 milyon dolar olan DYY giriş stoku 2014 yılında 9 milyar 2 milyon dolara; Kırgızistan'ın 2003 yılında 532 milyon dolara DYY giriş stoku 2014 yılında 3 
milyar 520 milyon dolara; Tacikistan'ın 2003 yılında 213 milyar dolar olan DYY giriş stoku 2014 yılında 1 milyar 885 milyar dolara çıkmıştır.

Tablo 7. Orta Asya Ülkelerine Yönelik DYY Giriş Stoku (2003-2013)

(Milyon Dolar)

\begin{tabular}{ccccc}
\hline & Kazakistan & Özbekistan & Kırgızistan & Tacikistan \\
\hline $\mathbf{2 0 0 3}$ & 17.587 & 929 & 532 & 213 \\
$\mathbf{2 0 0 4}$ & 22.376 & 1.106 & 582 & 251 \\
$\mathbf{2 0 0 5}$ & 25.607 & 1.297 & 627 & 306 \\
$\mathbf{2 0 0 6}$ & 32.879 & 1.471 & 1.256 & 645 \\
$\mathbf{2 0 0 7}$ & 44.590 & 2.176 & 983 & 1.013 \\
$\mathbf{2 0 0 8}$ & 59.035 & 2.888 & 1.380 & 862 \\
$\mathbf{2 0 0 9}$ & 71.846 & 3.730 & 1.429 & 993 \\
$\mathbf{2 0 1 0}$ & 82.648 & 5.366 & 1.698 & 1.164 \\
$\mathbf{2 0 1 1}$ & 107.396 & 7.001 & 2.413 & 1.292 \\
$\mathbf{2 0 1 2}$ & 119.944 & 7.564 & 2.674 & 1.556 \\
$\mathbf{2 0 1 3}$ & 125.079 & 8.250 & 3.320 & 1.625 \\
$\mathbf{2 0 1 4}$ & 129.244 & 9.002 & 3.520 & 1.885 \\
\hline
\end{tabular}

Kaynak: (UNCTAD, 2016).

2006-2012 y1lları arasında DYY girişi ortalama, Kazakistan GSYİH'sinin \%9,3'ü, Krrgızistan'ın GSYİH'sinin \%7,1'i, Tacikistan'ın GSYİH'sinin \%11,8'i, Özbekistan'ın GSYİH'sinin \%2,7'si kadar olmuştur. DYY girişleri, belirtilen periyotta bu ülkelerde oldukça dalgalı bir seyir izlemiştir. Tacikistan'da \%12 ile $\%-0,3$ arasında, Kazakistan' da \%5 ile \%12,4 arasında, Özbekistan' da \%1 ile \%3,2 arasında, Kırgızistan'da ise $\% 4$ ile $\% 11,2$ arasında değişmiştir. Yine bu periyotta DYY girişlerinin çoğunluğu büyük enerji ve maden yatırım projelerinden olmuştur (Asian Development Bank Institute, 2014).

Tablo 8. Orta Asya Ülkelerinde DYY Girişinin GSYİH'ye Oranı (\%)

\begin{tabular}{lccccccc} 
& \multicolumn{7}{c}{$(2006-2012)$} \\
\hline Kazakistan & $\mathbf{2 0 0 6}$ & $\mathbf{2 0 0 7}$ & $\mathbf{2 0 0 8}$ & $\mathbf{2 0 0 9}$ & $\mathbf{2 0 1 0}$ & $\mathbf{2 0 1 1}$ & $\mathbf{2 0 1 2}$ \\
Özbekistan & 9,4 & 11,4 & 12,6 & 12,4 & 5,0 & 7,7 & 7,5 \\
Kurgizistan & 1,0 & 3,2 & 2,5 & 2,6 & 4,2 & 3,2 & 2,1 \\
Tacikistan & 6,4 & 5,5 & 7,3 & 4,0 & 9,1 & 11,2 & 5,7 \\
\hline
\end{tabular}

Kaynak: (Asian Development Bank Institute, 2014).

Orta Asya ülkelerinde doğrudan yabancı yatırımların büyük kısmı greenfield (sıfırdan) yatırımlardır. Ayrıca, doğrudan yabancı yatırım akışları çoğunlukla ihracat odaklı, yerel piyasaya yönelik hizmet vermeyen genel itibari ile enerji ve petrol sektöründe yoğunlaşmış türdendir (Arazmuradov, 2012).

Kırgızistan mevzuatında herhangi bir sektöre özgü kısıtlama olmadığ1 gibi ülkenin yabancı yatırımcılara nispetten açık ve kâğıt üzerinde liberal bir yatırım rejimi mevcut. Ancak kurallar ve düzenlemeler net ve şeffaf bir şekilde uygulanıyor olmayabilir. Yabancı yatırımcılar Adalet Bakanlığında tescil işleminden geçerek çalışma izni alarak lisans ve onay prosedürlerini tamamlamak zorundadir (OECD and The World Economic Forum, 2011). Kirgizistan Cumhuriyetinde yabancı yatırımcılar herhangi bir sektör kısıtlaması olmadı̆̆ gibi \%100 mülkiyet hakkına sahiptir. Ayrıca, yatırımcılara sermaye, temettü ve diğer 
gelir çeşitlerini serbestçe kendi ülkelerine transfer hakkı tanınmaktadır (Paswan, 2013).

Özbekistan'da çeşitli sayıdaki sektör özel yatırıma kapalı veya sınırlı mülkiyet kısıtlamaları ve asgari sermaye zorunluluklarına tabidir. Hükümet tarafından ileri sürülen küçük ölçekli stratejik yatırımlara katılma hakkı tanınmamaktadır. Altın, uranyum, petrol, doğal gaz ve pamuk üreterek kendi kendine yettiğinden dolayı Özbekistan hükümeti bu alanlarda sıkı denetimini devam ettirmesine rağmen ülke ekonomisi büyüme göstererek dünya literatürüne "Özbek paradoksu" ifadesini kazandırmıştır. Ekonomideki yatırım hacmi o kadar yüksek olmasa da, Özbekistan hükümeti Coca-Cola, Newmont, British Amerikan Tobacco, Daewoo ve Uzbek Soil gibi büyük şirketleri kendi pazarına çekmiştir (Hoen \& Irnazarov, 2012).

Kırgızistan'da büyük yatırım yapan ortak girişimli yabancı şirketler Reemstma Kırgızistan Şirketi(sigara), Plaskap Bişkek Şirketi(ambalaj/şişeleme), Orta Asya Grubu(eğlence/tekstil), Hyatt Regency Bişkek(otelcilik), Coca-Cola, Kirgiz Petroleum Grup, Centera Gold olarak siralanabilir (The U.S. State Department, 2012).

Tacikistan'da büyük çaplı yatırımlar ve en az \%30 yabancı sermaye payı olan ortak girişimlere yatırımın büyüklüğüne bağlı olarak gelir vergisi muafiyeti iki ve beş yıl arasında değişen özel bir teşvik sunan yatırım rejimi açıklanmıştır. Hükümet herhangi bir şart getirmemekte ancak yerel içerik kullanımına önem vermektedir(OECD and The World Economic Forum, 2011).

Özbekistan Orta Asya ülkeleri arasında büyük ölçekte motorlu araç üreten tek ülkedir. General Motors ve Daewoo şirketleri ülkede üretim tesisleri kurmuştur. Özbekistan üretilen otomobillerin büyük ölçüde iç talebin karşılanması amaçlanırken zamanla Rusya ve diğer Orta Asya ülkelerine de ihracatı gelişmiştir. Ülke serbest ekonomik bölgelerine çok sayıda Çin ve Koreli şirketler tarafından endüstriyel alanda yatırım çekmiştir (Bendini, 2013). Ancak Özbekistan ekonomisi hala sıkı devlet kontrolü altındadır. Yabancı sermayenin transferini kısıtlamakta ve yabancı yatırımların yerel istihdam zorunluluğunu ileri sürmektedir. Adalet Bakanlığı'nda tescil edilmiş ve öncelikli sektörlere(bilgisayar bileşenleri, tekstil, inşaat malzemeleri, süt ürünleri üretimi) yatırım yapan ya da ulusal kalkınma hedeflerini(ihracat odaklı veya ithal ikameci) destekleyen girişimlere vergi muafiyetleri ve diğer ayrıcalıklar sunulabilmektedir. $\mathrm{Bu}$ ayrıcalıkların kullanılması ile elde edilen gelirlerin yeniden yatırıma aktarılması ve transfer edilmemesi şartı getirilmiştir(OECD and The World Economic Forum, 2011).

Kazakistan'da yabancı yatırımcıların uzun vadeli toprak kiralamaları için azami süre 49 y1l olarak kanunda belirtilmiştir. Bununla birlikte, tarımsal arazi sadece 10 yıllığına yabancılar tarafindan kiralanabilir. Kırgızistan' da yabancıların toprak sahibi olmalarına izin verilmez, ancak mülkiyet 99 yıllık süre boyunca çoğu durumda yatırım gereksinimlerine uygun olarak kiralanabilir. Bunun yanında, Tacikistan' da yabancılara 50 yıllığına toprak kullanımı ve kiralama hakkı verilmektedir. Yabanc1 mülkiyet konusunda herhangi bir yasal 
sınırlama olmamasına rağmen yatırımcıların devlet müfettişleri ile yaşadıkları sıkıntılar göz ardı edilemez seviyede. Özbekistan' da ise, yabancıların arazi mülkiyeti hakları sınırlı ve azami kira süresi 50 yıl olarak belirlenmiştir (OECD and The World Economic Forum, 2011).

\section{SONUÇ}

Orta Asya ülkelerinin bağımsızlıklarını elde etmelerinin ardından, dünya çapında yaşanan küreselleşme olgusu ile piyasa ekonomisine geçiş sürecinde daha yakından tanışmaları ve etkilerini daha yakından hissetmeleri oldukça sancılı olmuştur. Ülkeler Sovyet döneminde, endüstriyel uzmanlaşma ve çok aşamalı bir üretim zincirinde genel itibariyle tedarikçi durumundaydılar. Sınırların ayrılması, ekonomik bağlantıların ve ticari ilişkilerin sarsılması sonucu merkezi yönetim tarafindan dengelen bütçeler ve karşılanan sosyal harcamalar kesilmiş ve böylece ülke üretimi de sekteye uğramıştır. Geçiş ekonomisi olan bu ülkelerin piyasa mekanizmaları ve kurumsal altyapılarını yeniden inşa etmek ve işler hale getirmek için ülkeler her biri faklı politika ve strateji izlemiştir. Her bir ülke yetkilileri bu süreç içinde kendi yapısal ve ekonomik politikalarını kendileri belirlediklerinden her biri ayrı reform yolunu takip ederek oluşan yüksek enflasyon ve bütçe açıkları ile baş etmeye çalışmışlardır. Özelleştirme süreci ilk önce yerel çapta gerçekleştirilmeye çalışılmışsa da yeterli sermaye ve istihdam sağlamadığından başarısız olmuştur. Yetersiz olan tasarruflar ve yetkililerin piyasa ekonomisi alanında bilgi ve beceri eksikliği ülkeleri doğrudan yabancı yatırım çekmeye ve böylece piyasaya sermayenin yanında yeni teknoloji ve teknik bilgi getirmeye çalışmışlardır. Ülkeler yabancı yatırımlar sayesinde kalkınma ve ekonomiyi dengeye getirme çabası ile daha çok zengin yer altı kaynakları sayesinde cazibe yaratmışlardır.

Kırgızistan diğer tüm ülkelerde olduğu gibi yaşadığı yüksek enflasyon ve kamu gelirlerindeki eksilme yüzünden uluslararası örgütler tarafindan sağlanan borçlanma ve krediler sayesinde daha hızlı bir kalkınma stratejisi izleme yoluna koyulmuştur. Bu kadar hızlı serbest piyasa şartlarına uyum çabası içerisine girmesi 1998 yılında ülkenin Dünya Ticaret Örgütü üyeliğine kabul edilmesi ile ülkeye daha çok yatırım çekme umudu vermiştir. Ancak ekonomik reform sürecinin yavaşlığı, ülke yetkililerinin bu konudaki bilgi eksikliği ve yaygın olan yolsuzluk, piyasa ekonomisi için üretim birimlerinin yapılandırılmasındaki gecikmeyi tetiklemiştir.

Diğer ülkelerde de aynı koşullar baskınken sahip oldukları yer altı kaynakları sayesinde bu sürecin daha kolay atlatmalarına ve dünya piyasasına ayak uydurmalarına destek olmuştur. Bunların arasında Kazakistan'ın en avantajlı konumda olduğu söylenebilir.

Tacikistan bu ülkeler arasında beş yıllık bir iç savaştan çıkan ülke olarak en şansız olarak görülmektedir. Ülke ekonomisini kalkındırmak ve istikrar yoluna girmek için alüminyum ve pamuk sayesinde döviz geliri elde etmeye çalışmıştır. Diğer Orta Asya ülkelerine kıyasla oldukça geç başlayan özelleştirme ve reform süreci yatırımcıların ülkedeki yatırım potansiyelini fark etmeleri ve değerlendirmeleri için fırsat vermemiştir. 
Özbekistan bu ülkeler arasında daha temkinli bir özelleştirme ve yapısal dönüşüm süreci yaşamıştır. İzlediği politikalar itibariyle kademeli reform stratejisini takip etmeyi seçmiştir.

Elverişli kara yollarının eksikliği, mevcut olan ihracat için uygun altyapı ve demiryollarının kalitesizliği Orta Asya ülkelerinde doğrudan yabancı yatırımların önünde büyük engel teşkil etmektedir. Kurumsal altyapının zayıflığı yönetişimin aksaması ve yasaların uygulanması esnasındaki zorlukların ortaya çıkmasına neden olmaktadır. Bunlara ilave olarak ciddi boyutlara ulaşan gayri resmi süreçlerin ve bölgede yaygın görülen yolsuzluk olgusu ortak sorun olarak ülke yatırım potansiyellerini dünya çapında düşürmektedir (Paswan, 2013).

Kırgızistan Cumhuriyeti Hükümeti yatırım ortamının iyileşmesi ve çekici hal alması için son dönemde denetimler ve vergi mevzuatında bir dizi idari yapıda ve yasal mevzuatta değişime gitmiştir. Vergi tahsilâtı konusunda vergi idaresinde çeşitli mercilerin yapısal dönüşümü sağlanmıştır. Şirket tescilinin tek mercii tarafından yapılması esası ile gerekli prosedür sayısı azaltılmış ve süreç kolaylaştırılmıştır. Vergi oranları düşürerek sayıları yarı yarıya azaltmıştır. Bu uygulamalar neticesinde vergi yükünün hafifletilmesi ve önemli ölçüde vergi yönetiminin kalitesini geliştirmek amacıyla gerçekleştirilmiştir.

Diğer Orta Asya ülkelerinde olduğu gibi Kırgızistan'ın en çok doğrudan yabancı yatırım çeken sektörü madencilik ve maden arama faaliyetleri olarak ifade edilebilir. Diğer sektörlerin geliştirilmesi ve dünya ekonomisine entegrasyonun sağlanması, ülke ekonomisi ve piyasanın çeşitlendirilmesi yolu ile bunun da, büyük altyapı harcamalarının yapılması ise gerçekleşebileceği açıktır.

Kırgızistan' nın önemli cazibe yaratan tarafı Kırgızistan'ın diğer Orta Asya ülkelerine göre daha liberal bir piyasaya sahip olması ve dış piyasaya olan açıklığının getirdiği ticari fırsatları olarak belirtilebilir (Aslund, 2004).

\section{KAYNAKÇA}

Abdurazakov, Ş. İ. (2008). Экономика Кыргызстана, Перспективы интеграции в мировое хозяйство (Kırgızistan Ekonomisi- Dünya Ekonomisine Entegrasyon Perspektifleri). Тенденции экономического и демографического развития в Кыргызской Республике (Kırgızistan Cumhuriyetinin Ekonomik ve Demografik Gelişim Eğilimi). içinde Bişkek, Kırgızistan: Кыргызско-Российский Славянский Университет, Факультет Экономики (Kırgız- Rus Slavyan Üniversitesi, İktisat Fakültesi).

Ağcakaya, S. (2009, Nisan). Geçiş Ekonomilerinden Orta Asya Türk Cumhuriyetleri'nde Bütçe Yönetimi ve Mali Disiplin Sorunu. Akademik Bakış, 16.

Akkaya, Ş. (2003). Vergileme ve Doğrudan Yabancı Sermaye Yatırımlar. I. Ü. Íktisat Fakültesi Maliye Araştırma Merkezi Konferanslart(43-44).

Altay, A. (2001). Geçiş Ekonomilerinde Devletin Ekonomik Rolleri, Görevleri ve KOBİ'lerin Durumu. İ.Ü. İktisat Fakültesi Maliye Araştırma Merkezi Konferansları, 41. Seri.

Anisimov, A. М. (2011). Комментарий к оценке экономического эффекта присоединения Кыргызстана к Таможенному союзу ЕврАзЭС (Kırgızistan'ın Gümrük Birliğine Üyeliğinin Ekonomik Etkisinin Değerlendirmesi). Евразийская экономическая интеграция (Avrasya Ekonomik Entegrasyon Dergisi), 4(13).

Arazmuradov, A. (2012). Foreign Aid, Foreign Direct Investment, and Domestic Investment Nexus in Landlocked Economies of Central Asia. Economic Research Guardian, 2(1). 
Arıkan, Z. (2002). Geçiş Ekonomilerinde Mali Disiplin. Küreselleşme ve Geçiş Ekonomileri Uluslararası Sempozyumu. Yayın No:29 (3). Bişkek-Kırgızistan: Kırgızistan-Türkiye Manas Üniversitesi.

Asian Development Bank. (2014). Asian Development Outlook 2014: Fiscal Policy for Inclusive Growth. Mandaluyong City, Philippines: Asian Development Bank.

Asian Development Bank Institute. (2014). Connecting Central Asia with Economic Centers. Tokyo-Japan: Asian Development Bank Institute.

Aslund, A. (2004, June 17). The Kyrgyz Republic: Reinforce Economic Growth through Lower Taxes and Better Governance. Ekim 10, 2014 tarihinde The Carnegie Endowment for International Peace: http://carnegieendowment.org/2004/06/17/kyrgyz-republic-reinforceeconomic-growth-through-lower-taxes-and-better-governance/hrqq adresinden alınd 1

Aydemir, C., Arslan, İ., \& Uncu, F. (2012). Doğrudan Yabancı Yatırımların Dünya'daki ve Türkiye'deki Gelişimi. Kocaeli Üniversitesi Sosyal Bilimler Enstitüsü Dergisi(23).

Aytemiz Seymen, O., \& Çeken, H. (2004). Küreselleşme ve Çok uluslu İşletmelerin Çalışma İlişkileri Üzerindeki Etkileri: Makro ve Mikro Boyutta Bir Değerlendirme. Süleyman Demirel Üniversitesi İktisadi ve İdari Bilimler Fakültesi, 9(2).

Azam, M. (2010). Economic Determinants of Foreign Direct Investment in Armenia, Kyrgyz Republic and Turkmenistan: Theory and Evidence. Eurasian Journal of Business and Economics, 3(6).

Balcılar, M. (2002). Geçiş Ekonomilerinin Büyüme Etkinliklerinin Bir Değerlendirmesi. Küreselleşme ve Geçiş Ekonomileri Uluslararası Sempozyumu. Yayın No:29 (3). BişkekKırgızistan: Türkiye Manas Üniversitesi.

Bayraktar, F. (2003). Dünyada ve Türkiye'den Doğrudan Yabancı Sermaye Yatırımları. Ankara: Türkiye Kalkınma Bankası A.Ş. Araştırma Müdürlüğü.

Bendini, R. (2013). Uzbekistan: Selected trade and economic issues. European Parliament Policy Department, Directorate-General for External Policies. Brussels-Belgium: European Union.

Crivelli, E. (2013). Fiscal impact of privatization revisited: The role of tax revenues in transition economies. Economic Systems, 37(2).

Çokgezen, M. (2004, Mart). Corruption in Kyrgyzstan: The Facts, Causes and Consequences. Central Asian Survey, 23(1).

Değer, M. K., \& Emsen, Ö. S. (2005). Geçiş Ekonomileri ve Türkiye'de Doğrudan Yabancı Sermayenin Dinamikleri. Erzurum: Atatürk Üniversitesi Yayınları (Araştırma Serisi No:92).

Dowling, M., \& Wignaraja, G. (2006). Central Asia: Mapping Future Prospects to 2015. Manila, Philippines: Asian Development Bank.

DPT. (2000). Doğrudan Yabancı Sermaye Yatırımları. Sekizinci Beş Yıllık Kalkınma Planı, Özel İhtisas Komisyonu Raporu, Ankara.

Dural, B. Y. (2007). Geçiş Ekonomileri-Plandan Piyasaya (1. Baskı b., Cilt Yayın No:1780). İstanbul: Beta Yayınları.

EBRD. (2014, Ekim 01). Main macroeconomic indicators. http://tr.ebrd.com/tr13/en/index.php?option=com_content\&view=article\&id=40\#mainmacroeconomic-indicators adresinden alınmıştır

Egeli, H. A., \& Emsen, S. (2002). Geçiş Ekonomilerinin Makroekonomik Performansları ve Kırgızistan Üzerine Bir Değerlendirme. Küreselleşme ve Geçiş Ekonomileri Uluslararası Sempozyumu. Yayın No: 29 (3). Bişkek- Kırgızistan: Kırgızistan- Türkiye Manas Üniversitesi.

Extractive Industries Transparency Initiative (EITI). (2011, Mart 1). Kyrgyz Republic - Extractive Industries. Ekim 2014, 01 tarihinde Extractive Industries Transparency Initiative (EITI): https://eiti.org/KyrgyzRepublic adresinden alınd1

FAO. (2015). Kyrgyzstan-Agriculture sector. Şubat 13, 2015 tarihinde FAO Country Profiles: http://www.fao.org/countryprofiles/index/en/?iso3=KGZ adresinden alınd 1

Fitzherbert, A. (2006). Country Pasture/Forage Resource Profiles -Kyrgyzstan. Şubat 15, 2015 tarihinde 
http://www.fao.org/ag/AGP/AGPC/doc/Counprof/PDF\%20files/Kyrgyzstan.pdf adresinden alınd 1

Gedikli, A. (2011). Çok Uluslu Şirketler ve Doğrudan Yabancı Yatırımların Gelişmekte Olan Ülkelerin Kalkınması Üzerine Etkileri. Girişimcilik ve Kalkınma Dergisi, 6(1).

Gökbunar, R., Yıldıran, M. \& Koç, E. (2016). Türki Cumhuriyetlerde Finansal Regülasyon Uygulamalarının Değerlendirilmesi. TiSK Akademi, 11(21).

Havrylyshyn, O., \& Wolf, T. (1999, June). Determinants of Growth in Transition Countries. Finance and Development, 36(2).

Hoen, H. W., \& Irnazarov, F. (2012). Market reform and institutional change in Kazakhstan and Uzbekistan. Paradoxes and prospects. J. Ahrens, \& H. W. Hoen içinde, Institutional Reform in Central Asia. Politico-economic challenges (Cilt (Central Asian Studies; No. 27)). London / New York : Routledge.

Houérou, P. L. (2012, May 15). The Investment Climate and the Environment of Doing Business in the Kyrgyz Republic. Ekim 2014, 01 tarihinde World Bank Group: http://www.worldbank.org/en/news/speech/2012/05/15/the-investment-climate-and-theenvironment-of-doing-business-in-the-kyrgyz-republic adresinden alınd 1

IMF. (1993). Balance of Payments Manual: Fifth Edition. Wahsington D.C.

İnci, A., \& Şahbazov, R. (2000, Temmuz). Globalleşme Sürecinde Teşviklerin Yeri ve Önemi: Avrupa Birliği ve Türkiye Açısından Genel Bir Değerlendirme. Vergi Dünyası Dergisi(227).

Investment Promotion Agency. (2015, Şubat 13). Investment promotion agency under the ministry of economy of the Kyrgyz Republic. http://www.invest.gov.kg/o_kirgizskoy_respublike/pribilnie_otrasli/legkaya_promishlenn ost.html adresinden alınmıştır

İstanbul Ticaret Odası. (2007). Türkiye İçin Model Olabilecek Ülkelerde Uygulanan Teşvik Uygulamaları ve Ülkemize Uygulanabilirliği (Cilt Yayın No: 2007-51). İstanbul: İstanbul Ticaret Odas1.

Jenish, N. (2014). Экспортно-ориентированное развитие МСБ в Кыргызстане: швейная промышленность (Kırgızisatnda İhracat Odaklı Kobilerin Gelişimi: Tekstil Sanayi). Университет Центральной Азии, Доклад №26 (Orta Asya Üniversitesi Raporu No: 26).

Kar, M., \& Tatlısöz, F. (2008, Aralık). Türkiye'de Doğrudan Yabancı Sermaye Hareketlerini belirleyen Faktörlerin Ekonometrik Analizi. K.M.U. I.I.B.F. Dergis, 10(14).

Karaca, S. S. (2010). Uluslararası Sermaye Hareketleri ve Kriz Sonrası Görünüm. Sosyal Bilimler Araştırmaları Dergisi(1).

Karagöz, K. (2007). Türkiye'de Doğrudan Yabancı Yatırım Girişlerini Belirleyen Faktörler: 19702005. Jornal of Yaşar University, 2(8).

Kaymakçı, O. (2013). Küresel Ekonomide Çok Uluslu Şirketler ve Türkiye'deki Yansımaları, Y11:2013, Cilt:11, Say1:1. Celal Bayar Üniversitesi Sosyal Bilimler Dergisi, 11(1).

KCMMO. (2011). Nalogi i Pravo Dergisi Eki(No:3).

Koçtürk, O. M., \& Eker, M. (2012). Dünyada ve Türkiye'de Yabancı Sermaye Yatırımları ve Çok Uluslu Şirketlerin Gelişimi. Tarım Ekonomisi Dergisi, 18(1).

Koyame-Marsh, R. O. (2011, October). The Complexities of Economic Transition: Lesson Form The Czech Republic And Slovakia. International Journal of Business and Social Science, 2(19).

Levina, M. (2014, Mart 28). Investment Promotion Agency established in Kyrgyzstan «The Times of Central Asia». Ekim 1, 2014 tarihinde "24.kg" News Agency: http://www.eng.24.kg/bigtiraj/169697-news24.html adresinden alınd1

Libman, A. М. (2009). Интеграция снизу», в Центральной Азии (Orta Asya'da Aşağıdan Yukarı Entegrasyon). Евразийская экономическая интеграция (Avrasya Ekonomik Entegrasyonu), 1(2).

Musaev, M. (2013). Nationalization of Kumtor: Possible Consequences For The Economy of Kyrgyzstan. Master's thesis , Central European University, Department of Economics, Budapest, Hungary. 
Muter, N. B., Özdil, T., \& Yılmaz, C. (2002). Globalleşmenin Gelişmekte Olan Ülkeler Üzerindeki Etkileri. K. v. Sempozyumu (Dü.), Kongreler Dizisi: 3. içinde Bişkek-Kırgızistan: Kırgızistan- Türkiye Manas Üniversitesi Yayınları: 29.

OECD. (1996). Detailed Benchmark Definiton of Foreign Direct investment: Third Edition. Paris.

OECD and The World Economic Forum. (2011). Competitiveness and Private Sector Development: Central Asia 2011. Paris: OECD Publishing.

Paswan, N. K. (2013). Investment Cooperation in Central Asia: Prospects and Challenges. India Quarterly, 69(1).

Penev, S. (2007, April). Investment Climate and Foreign Direct Investment Trends in the South Caucasus and Central Asia. South East European Journal of Economics and Business, 2(1).

Polterovich, V. (2006). Institutional Reform Strategies:Promising trajectorie. Economis and Mathematical Methods Journal, 42(1). Aralık 29, 2013 tarihinde https://mpra.ub.unimuenchen.de/22000/1/MPRA_paper_22000.pdf adresinden alınd1

Sakınç, S. (2005). Geçiş Ekonomileri ve Orta Asya Türk Cumhuriyetlerinde Ekonomik Reformlar. Manisa: Emek Matbaacilık.

Sayrakunova, A. (2010). Orta Asya Ülkelerinde Uluslararası Ticaretin Gelişimi, Sorunları ve Öncelikleri (Kırgızstan Örneği). 9. Türk Dünyası Ekonomi, Bilişsim ve Kültür Forumu. Ankara: Hacettepe Üniversitesi Türkiyat Araştırmaları Enstitüsü \& T.C. Başbakanlık Dış Ticaret Müsteşarlığı.

Sezgin, Ş., Yıldız, S., \& Sezgin, S. (2011). Yabancı Sermaye Yatırımları ve Türkiye'de Yabancı Sermaye Sorunu. C. İ. Türk Dünyası Araştırmaları Vakfı (Dü.), 8. Uluslararası Türk Dünyası Sosyal Bilimler Kongresi. içinde Celalabat-Kırgızistan: Türk Dünyas1 Araştırmaları Vakfi.

Staehr, K. (2003). Reforms and Economic Growth in Transition Economies: Complementarity, Sequencing and Speed. Helsinki: Bank of Finland Institute for Economies in Transition (BOFIT).

Supataeva, G. T. (2011). Политика государства по привлечению иностранных инвестиций: анализ и перспективы (Yabancı yatırım çekmeye yönelik hükümet politikası: analiz ve beklentiler). Вестник Томского государственного университета.Экономика (Tomsk Devlet Üniversitesi Bülteni. Ekonomi), 4(16).

Susam, N. (2008). Doğrudan Yabancı Yatırımlardaki Gelişmeler ve Bu Yatırımlar İçin Belirleyici Unsurlar: Türkiye Bulguları. Akademik Incelemeler Dergisi, 3(2).

The U.S. State Department. (2012, June). 2012 Investment Climate Statement - Kyrgyz Republic. (B. o. Affairs, Düzenleyen) The U.S. State Department: http://www.state.gov/e/eb/rls/othr/ics/2012/191179.htm adresinden alınmıştır

Trading Economics. (2014). Узбекистан - Уровень инфлящии (Özbekistan - Enflasyon oranı). Ekim 10, $2014 \quad$ tarihinde Trading Economics: http://ru.tradingeconomics.com/uzbekistan/inflation-cpi adresinden alınd 1

UN. (2010). Kyrgyzstan Overview. Şubat 2015, 13 tarihinde UN in Kyrgyzstan: http://www.un.org.kg/en/kyrgyzstan/overview adresinden alınd

UNCTAD. (2013). Kyrgyzstan-National Services Policy Review, 2013.

UNCTAD. (2015). World Investment Report 2015. UNTAD, Nwe York \& Geneva.

UNCTAD. (2016). Foreign direct investment: Inward and outward flows and stock, annual, 19802014. Şubat 15, 2016 tarihinde UNCTADSTAT: http://unctadstat.unctad.org/wds/TableViewer/tableView.aspx adresinden alınd1

UNDP. (2015, Şubat 13). О Кыргызской Республике (Kırgızistan Hakkında). ПРООН в Кыргызской Республике (Kurgiz Cumhuriyeti'nde UNDP): http://www.kg.undp.org/content/kyrgyzstan/ru/home/countryinfo/ adresinden alınmıştır

Ünver, M. (2012). Kırgızistan Kırılgan Hatlar Ülkesi. M. S. Kafkasyalı içinde, Bölgesel ve Küresel Politikalarda Orta Asya. Ankara-Türkistan: Hoca Ahmet Yesevi Uluslararası Türk-Kazak Üniversitesi.

World Bank. (2013a). Kyrgyz - Country partnership strategy for the period FY14-17. Washington DC: World $\quad$ Bank. Ocak 12, 2015 tarihinde 
http://documents.worldbank.org/curated/en/2013/06/17965636/kyrgyz-countrypartnership-strategy-period-fy14-17 adresinden alınd 1

World Bank. (2013b). Doing Business 2014: Understanding Regulations for Small and MediumSize Enterprises. Washington, DC: World Bank Group.

World Bank. (2014). World Development Indicators 2014. Washington, DC.

World Bank Group. (2010). Investment Climate in the Kyrgyz Republic as Seen by Small and Medium Enterprises. Bishkek, Kyrgyz Republic: IFC Investment Climate Advisory Services .

World Bank Group. (2015). World Bank Group-Kyrgyz Republic Partnership Program Snapshot. Şubat 15, $2015 \quad$ tarihinde http://www.worldbank.org/content/dam/Worldbank/document/KyrgyzrepublicSnapshot.pdf adresinden alınd 1

World Economic Forum. (2015). The Global Competitiveness Report 2014-2015: Geneva: World Economic Forum.

WTO. (2013). Trade Policy Review-Report by Kyrgyz Republic. World Trade Organization.

Yereli, A. B., Yıldız, S., \& Ayyıldız, Y. (2007, Kasım). Kırgızistan'da Doğrudan Yabanc1 Yatırımlara Yönelik Sermaye Yatırımları. Mali Pusula, 3(35).

Национальный статистический комитет Кыргызской Республики (Kirgizistan Cumhuriyeti Milli İstatistik Komitesi). (2014). Деятельность предприятий с иностранными инвестицияли 2009-2013 (Kırgızistan Cumhuriyetinde Yabancı Sermayeli Şirketlerin Faaliyetleri 2009-2013). Ekim 01, 2014 tarihinde http://stat.kg/images/stories/docs/tematika/fin/Deyt_SP_KR_2009_2013.pdf adresinden alınd1

\section{SUMMARY}

Insufficient capital accumulation is the most important obstacle deterring countries from attaining the investment level required for their development. In this case, for countries which do not have sufficient savings for investment, in other words, for countries which have savings deficit, it becomes mandatory to make use of foreign financing sources. This brings up the concept of foreign investments. There are some factors influencing the entry of direct foreign investments in a country. Some of these factors may be listed as follows: the size of the market, incentive tax privileges, economic and political factors of the country, the similarity of social and cultural conditions in the country in which the investment will be made, tax related regulations in the country of the foreign investor and anti-monopoly policies.

After the fall of the Berlin Wall in 1989, three communist countries, the Czech Republic, Yugoslavia and the Soviet Union broke up into 22 separate countries. These countries which were in the process of new independence were called "transition economies." It is quite a complicated and long lasting process to ensure the transition from an economic and political structure based on central planning system to market economy and then the transformation. Having gained their independence with the dissolution of the Soviet System, the former socialist countries began making efforts for important economic reforms in the process of transition to market economy. Central Asian countries are among these groups of countries. In Central Asian countries the transition process had different forms in each country as a result of the policies they followed under the economic, political and structural conditions. The benefits and effects provided for country 
economies by direct foreign investments that were brought by privatisation process which is important for ensuring the generation of capital for countries of transition economy are still observable. It is a truth that most of these countries are dependent on direct foreign investments and that they have a very low level of welfare.

Foreign investment flows in countries in that region are significantly variable. The country which attracts the highest amount of direct foreign investment in the region is Kazakhstan. It is followed by Uzbekistan and Kyrgyzstan respectively. The country which attracts the lowest amount of direct foreign investment in the region is Tajikistan.

Lack of convenient roads, the infrastructure suitable for only the existing export and low quality of railways pose a great obstacle before direct foreign investments in Central Asian countries. In addition, illegalities of serious sizes and corruption which is widely seen in the region are factors in common hindering investments into these countries.

As one of these countries Kyrgyzstan is attracting more attention every other day due to its strategic position in Central Asia, its liberal economy and moderate approach. Trying to get rid of the traces of the transition period, this country established serious legal and structural regulations and practices in order to promote foreign investments. From the very first day of independence, the development of the relevant legislation started with the adoption of the "Law on Foreign Investments in the Republic of Kyrgyzstan" in 1991. Then, another Law on Foreign Investments in the Republic of Kyrgyzstan was enacted on $24^{\text {th }}$ September 1997 for the purpose of regulating the activities of foreign investments in the Republic of Kyrgyzstan and building a legal foundation for these activities. The latest relevant Law on Foreign Investments in the Republic of Kyrgyzstan is the one enacted on $27^{\text {th }}$ March 2003. With this latest law, the difference between foreign investors and native investors has been totally abolished, and it has been stated that state-granted privileges will be for determined regions and priority sectors.

As it is also the case in most of Central Asian countries, mining and prospecting activities are sectors attracting the most direct foreign investments in Kyrgyzstan. As the greatest foreign investor company in the country in gold mining sector Kumtor constituted alone in $201111,7 \%$ of the country's GDP, which represented $51,1 \%$ of total export of the country. Being geographically close to rapidly developing countries such as China, Kazakhstan and Russia, Kyrgyzstan has the potential to seriously extend its export. Despite these advantages, though, the country is still focused on agriculture (cotton, tobacco, leather processing), service, mining (largely gold), construction materials and light industrial production. 